\title{
Hafif Çelik Modüler Kutu Yapım Sistemlerinin Gelişim Süreci ve Temel Yapım ilkeleri
}

Kabul tarihi/Final Acceptance: 25.10 .2018

\section{Giriş}

II.Dünya Savaşı nedeni ile çok sayıda binanın yerine yeni yapıların hızlı inşa edilmesi ihtiyacı yapı sektörünü endüstrileşmiş yapım yöntemlerini geliştirmeye yönlendirmiştir. Özellikle bu dönemde ön üretimli modüler kutu sistem, konut, okul, yurt gibi farklı fonksiyonlu binaların çok sayıda üretilebilmesine imkan vermiştir. Modüler kutu sistemler fabrikada yüksek seviyede bitimiş endüstrileşmiş ürünlerdir. Nakliye koşullarına bağlı olarak belirli boyutlarda üretilen modüler kutular, döşeme, duvar ve tavanları ile birlikte tanımlanmış mekanlara sahip olması ilk bakışta sistem hakkında olumsuz kanı oluştursa da, tasarımcının farklı modül tipleri ile bir lego düzenlenişine benzer farklı plan tipleri ve cephe tasarımlarını yapması mümkündür.

Endüstrileşmenin son noktası olarak kabul edilen modüler kutu sistemler, yapım süresinin kısalığı, hızlı montaj, malzeme kayıplarının en aza indirgenmesi gibi çok sayıda avantaja sahip olan kaliteli ve sürdürülebilir binaların yapımına imkan verir. Yapı bileşenlerini şantiye dişında üretmek daha kontrol edilebilir koşullar sağlar ve bileşenlerin üretiminde daha fazla kaliteye ve hatasızlığa olanak tanır. Tamamlandıktan sonra sistemler veya bileşenler uygun zamanda monte edilmek üzere bir şantiye alanına nakliye edilir. Bu teknikler doğru uygulandığında daha düşük proje maliyetlerinin daha kısa iş programlarını, işgücünü ve malzemenin daha verimli kullanımının garantisini sunar (Eren, Ö., 2014; Weller, K., 1989). Beton, ahşap ve çelik olarak üretilen modüller farklı işlevleri yerine getirecek şekilde üretilirler. Sadece taşıyıcı sistem değil aynı zamanda elektrik, sıcak su tesisatı gibi mekanik sistemlerin montajı da fabrikadaki üretim aşamasında kalite kontrolleri yapılarak yerleştirildiği için artan kalite ile birlikte şantiyede ki işçilik süresi azalır. Fabrikalarda üretilen modüllerde yapılan kalite kontrolleri, hata payını en aza indirmesinin yanı sıra güvenli yapımı da beraberinde getirmektedir.

\section{Modüler Yapımın Tarihçesi}

1830'da Londra'da marangoz ve inşaat ustası olan H. John Manning, Avustralya'ya göç eden oğlu için konforlu, tasarımı oldukça basit, kolay inşa edilmiş bir kır evi tasarladı. Göçmenler için Manning Portable Colonial Cottage olarak bilinen prefabrike ahşap çerçeveli ve dolgu bileşenli ev, prefabrikasyon alanında ilk önemli eser olarak karşımıza çıkar (Şekil 1). Bu sistem John Loudon'in "Köy Evi, Çiftlik Evi, Villa ve Mobilya Ansiklopedisi" nde yazdığı tanımlamada, yivli dikmeli, plakalı döşemeli ve üçgen kafeslerden oluşan bir sistem olarak tanımlanmıştır. Köy evinin içindeki döşeme plakaları yivli dikmelerin arasına yerleştirilmiş standart ve değiştirilebilir özelliklerdedir. Konutun her bir birleşeni 
tek bir kişinin taşıyabileceği ağırlıkta ve boyutlarda, standart bir anahtar ile basitçe bulonlama ve vidalama yöntemleri ile kurulabiliyordu. Manning sistemi olarak bilinen bu konutlar, modüler kutu sistemlerin de temellerini atarak ön üretimin temel kavramlarını, boyutsal koordinasyon ve standardizasyon kavramlarını ön plana ç1karmışt1 (Smith,R.,2010; G. Herbert, 1978).

19. yüzyılda Britanya'dan gelen ahşap mimari uygulamaları Amerika Birleşik Devletleri'nde balon çerçeveli binaların yapımının başlangıcı olduğu varsayılmaktadir. Augustine Taylor, 1833 yilında Chicago'daki Fort of Dearborn yakınların-

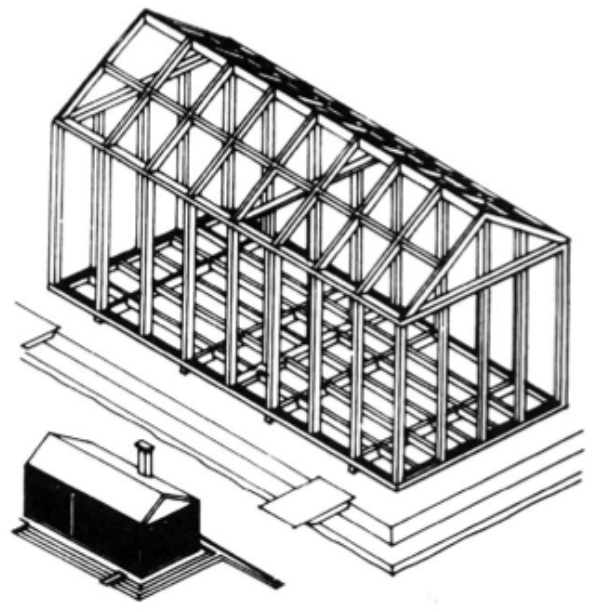

Şekil: I

Göçmenler için Manning Taşınabilir Ahşap Kır Evi. 19. yüzyılda Yeni Zelanda ve Güney Afrika'daki hizla genişleyen Ingiliz kolonilerinin ihtiyaçlarını hızla karşılayan çözümdü (Smith, R.,2010)

daki St. Mary Kilisesi'nin inşasında balon çerçeveyi ilk kez uygulamasıyla yeni bir dönem başlatır. Platform ve balon çerçeve olarak iki şekilde düzenlenen hafif çerçeve yapımını iki ana faktör tetiklemiştir, bunlar; yeni ülkede çok sayıda odun tedariki ve seri üretilen demir çivi ve kereste fabrikalarıyla hızla genişleyen endüstriyel ekonomi. Bu sistem ile o dönem için imkansız görünen bir ilkbahar ve yaz döneminde 150 ev inşa edilebildi ki bu o dönem koşulları için olağanüstü bir başarı idi. Aynı yıllarda Sanayi Devriminin gelişiminde önemli paya sahip olan çelik malzemenin bulunması bilim adamlarının bu malzemenin yangına dayanım, yüksek taşıyıcılık kapasitesi, hafiflik vb özelliklerini geliştirme çalışmaları ile ahşap malzeme yerini çeliğe bırakmaya başlamıştır. Çelik endüstrisindeki gelişmeler ile ahşap iskelet sistem kuruluş prensiplerine sahip hafif çelik yapım sistemlerinin de temelleri atıldı. Yirminci yüzyıl sanayileşmesi, ilk olarak, 1908 tarihli Henry Ford'un T Modeli için geliştirilen üretim yöntemleriyle tanımlandı. Kitlesel üretimin büyük nesneler üretebileceği ve bunu yaparak ürünlerin birim maliyetini önemli ölçüde azaltabileceğinin canlı kanıtı oldu. 1910'da, Bauhaus'un kurucusu Walter Gropius, "yeni bir çağ için yeni bir mimarlık" çağrısında bulunduğunda, sanayileşmiş konutları düşünüyordu. Film endüstrisi bile, Buster ve karısının yeni bir prefabrike ev inşa ettiklerini Buster Keaton filminde (1921) yayınlayarak prefabrike yapıları popüler kültüre itti (Resim 1) (Smith,R.,2010; URL-1,URL-5).

1900'lerin başlarında modüler sistemlere mimari ifade kazandıran Walter Gropius mimarlıkta sanayileşme ve toplumsal eşitlik konularıyla ilgileniyordu. Gropius, Behrens'in endüstriyel estetiğini kullanarak, mutlak işlevi ifade eden bir mimari yarattı. 1919'da Bauhaus'u kurdu. Prefabrikasyona olan ilgisi, Bauhaus'daki günlerden açıkça görülüyor ve konut maliyetini azaltmak için fabrika dışı teknolojiden yararlanıyordu. 1910'da, Behrens'in ofisi ile işbirliği içinde olan Alman Elektrik Şirketi için önüretimli konut önerdi.

Gropius ve Konrad Wachsmann işbirliğinin eseri olan, ABD pazarı için bir savaş zamanı teklifi olarak tasarlanan "Ambalajlı Ev" belki de prefabrike mimarlık düşüncesine en çok katkıda bulunan ürün oldu. 1954 yılında, mobil ev endüstrisi, hızlı bir şekilde inşa edilen konut ihtiyacına paralel olarak yaygınlaşmıştır. ABD'de de modüler konut üretimi İngiltere'deki geçici konut programlarına benzer şekilde, tamamen bir fabrikada şasi üzerinde bir modül olarak inşa ediliyor ve daha sonra kam-

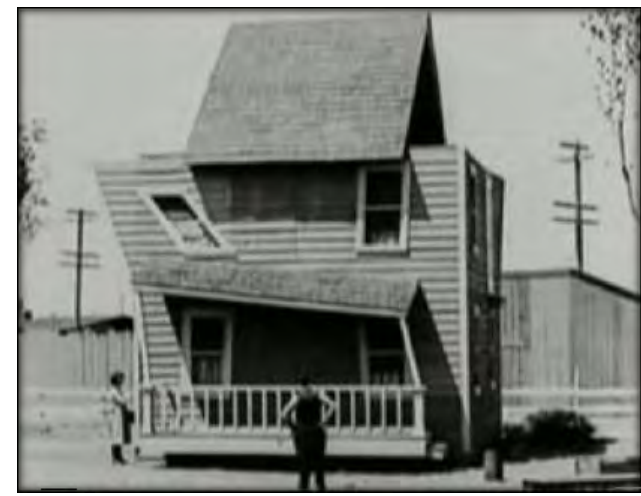

Resim: I

Buster Keaton filmi için yapılan prefabrike eV, 1921 (URL-s) 
Resim: 2

1970'lerin sonunda, Utah'in Salt Lake City bölgesinde çeuresi verandalı, tek açıklıklı bir mobil ev (URL-S)

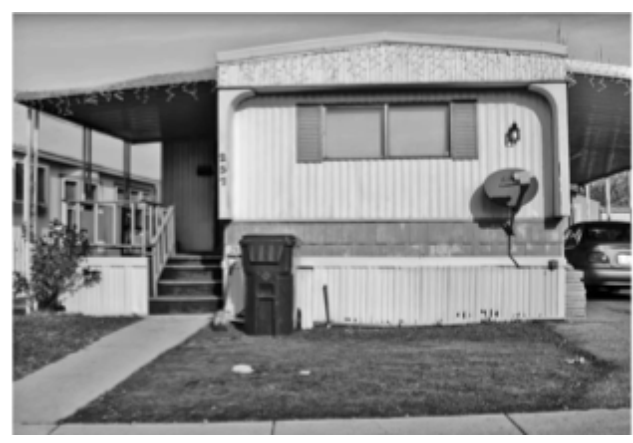

yona taşı1nıyordu. 1958'lere gelindiğinde ABD'de tek aileli toplam konut stoğunun \%25'i modül konut anlayışı ile üretilmişti (Resim 2) (Smith,R.,2010; URL-5).

2. Dünya Savaşı sonrasında ortaya çıkan büyük konut açığını karşılamak için teknolojideki gelişmelere bağlı olarak yeni yöntem arayışına gidildi. Özellikle hızlı, güvenli ve kaliteli konut ihtiyacını karş1lamak üzere çok sayıda üretilebilen prefabrikasyona dayalı modül kutu sistemler 1930'larda Sovyet Sosyalist Cumhuriyetler Birliği'nde uygulanmaya başladı. Betonarme olarak üretilen bu modüller, fabrikada ince işleride bitirilerek şantiyeye getiriliyordu fakat ağırlıklarının vinç kapasitesini zorlaması, boşluk açılmasındaki zorluklar, sınırlı tasarım imkanları vb. diğer dezavantajlarla birlikte bir müddet sonra beklenilen ihtiyaca cevap vermediği için kullanımı terk edilmiştir (Smith,R.,2010; Shih, 2002).

Le Corbusier modüler konut yapım fikrini, dar gelirli aileler için geliştirdiği "Machine for Living" tasarımlarında da kullanmıştır. Araştırmacılar Le Corbusier'in bu yaklaşımını iki farklı açıdan ele alırlar. Öncelikle Corbusier'in konutu makine anlayışı ile ele alıp tasarlamasındaki ana etken, ilk kullanıcısından sonra ikinci kullanıcıların konutta bir takım değişiklikler yapabilmeleridir. Konutların sadece iç mekanlarındaki bölücü duvarlarında ve renkde değil aynı zamanda çatı ve cephe boşluklarında da yapısal değişiklikler yapmaları, Corbusier'in binaların değişen kullanıcılara bağlı olarak değiştirilebilir, sökülüp-takılabilir yapı elemanlarından oluşan yapım sistemlerine yönelinmesinin ihtiyaç olduğunu ortaya koymuştur (Baldwin, J.,1996; URL-20). Birinci Dünya Savaşı'ndan sonra tanınmayacak hale gelen Avrupa, özellikle çok sayıda konuta ihtiyaç duydu. Konutlar için bu büyük talep, mimarlara fikirlerini yerine getirmeleri için daha fazla fırsat verdi. O dönemde Le Corbusier seri üretim teknolojisinin uygulanması ve konut standardizasyonu ile çok ilgiliydi. Ona göre, konut sorunu "zamanımızın sorunu" idi ve modern konutların yarattığı karışıklıklara bir çözüm bulmak gerekiyordu (Chia-Chang Hsu, Chih Ming Shis, 2006).

Modüler kutu mimarisinin temelini atan Modernist mimar Le Corbusier, "geleceğin konutu"nu, seri üretilen araba üretimi ile aynı şekilde olacağını söylemiş, çalışmalarını da bu yönde ilerletmiştir. İdeal konutun kontrol altında fabrikalarda seri üretime dayalı ve arabalar gibi kullanıcıların konutlarını istedikleri yere taşıyabilmeleri gerektiğini savunmuştur. Bu noktadan yola çıkışla Fuller çalışmalarına önce ahşap sonra da çelik elemanlarla sürdürmüş̧ür. 1929 yılında tamamladığı Dymaxion Evini, kullanıcıların evlerini başka bir yere taşıyabilecekleri, her bölgedeki koşullara uyum sağlayacak performansı gösterecek şekilde tasarlamıştır (Resim 3). Konutun her bir odası esnek tasarlanmış istenildiğinde çıkarılıp yerine yenisinin takılabilleceği şekilde detaylandırılmıştır. Kubbe formundaki çatıda menfezlerin yerleştirilmesi ile de tüm mekanlar doğal havalandırılarak da enerji verimliliği ilkesi ortaya koyulmuştur (Chia-Chang Hsu, Chih Ming Shis, 2006; Baldwin, J.,2012; Altın M., 2013). Fuller'in Dymaxion Evi gerçek hayata geçirilememiştir ama daha sonra aynı prensiplere dayalı olarak tasarladığı Wichita Evi’nin prototipi yapılmıştır. Her biri $5 \mathrm{~kg}$ ağırlığından fazla olmayan standart elemanlardan tasarlanan Wichita Evi’nin strüktürel elemanları şantiye alanına paketler halinde getirilip bir silindir dikmeye asılma yöntemi ile taşıtılan bir yapı haline sadece 6 işçi ile bir günde kurularak getirilmiştir. Konutun jeodezik kubbesi az miktardaki malzeme ile büyük bir alanın kaplanabileceğini göstermiştir. Cephede kaplama malzemesi olarak aluminyum paneller kullanılmıştır (Resim 4) (Kronenburg, R., 1995; Burns, C., 2001; Altın M., 2013). 

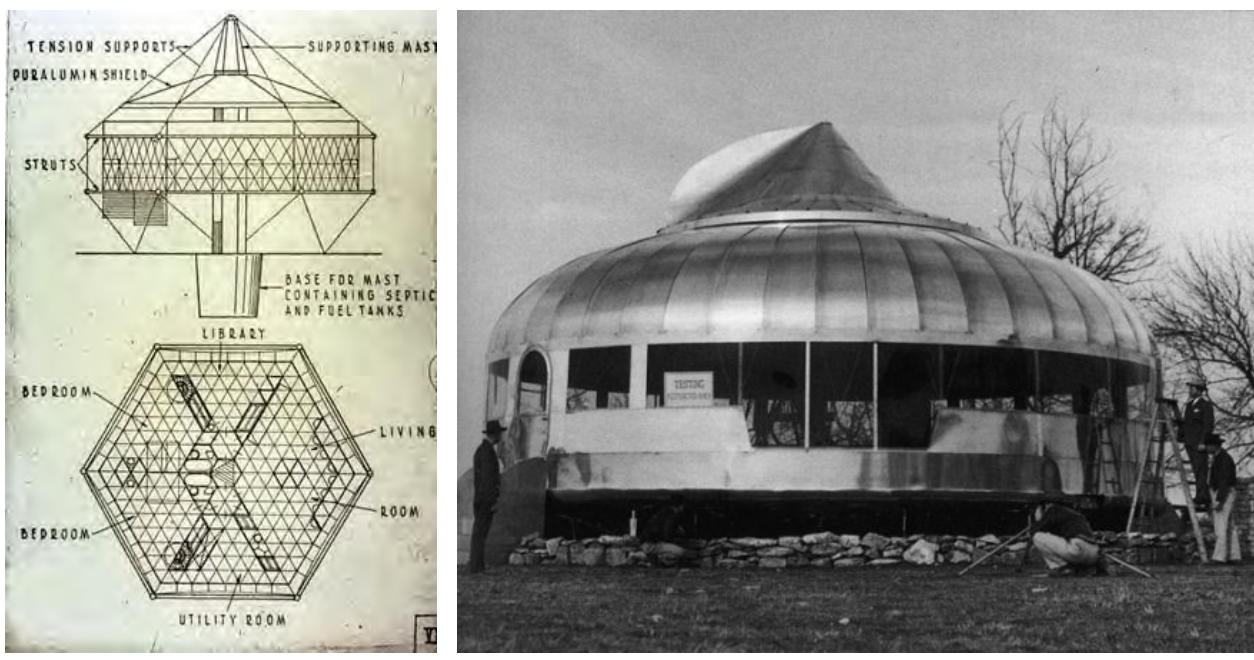

1930'larda Fransa'da modüler konut alanında yeni fikirler ortaya koyan asıl mesleği mobilya tasarımcılığı ve imalatçılığı olan Jean Prouve modül kutu sistem konseptinde tasarladığı tatil evinde, mevcut en gelișmiș üretim yöntemlerini kullandı. Prouve 1.Dünya Savaşı sonrası hızlı ve taşınabilir konut tasarımı konularında çalıştı. Prouve tasarımlarında başından beri soğuk şekillendirilmiş çelik çerçeve ve ahşap paneller kullanıyordu. 1949'da, Paris yakınlarındaki Meudon Evleri olarak bilinen, günümüzde de hala kullanılan 25 evi bu prefabrike konut anlayışı ile yapmıştır. Prouve'un çalışmalarındaki ana hedef atıkları en aza indirmek ve yararı en üst düzeye çıkarmak ve mümkün olan en büyük mekanı en verimli strüktür ile yapmakdı, bu amacını da hafif çelik sistemleri kullanarak başard1 (Smith,R., 2010; URL-6,URL-7).

1950’lerde Fransız mimarisindeki katı anlayışın aksine, Prouvé konutların ihtiyaç duyulan yere taşınabilmesi gerektiğine inanıyordu. Bu fikri sadece evler ile sınırlı kalmadı, okullar, kiliseler ve fabrikalarında bu şekilde tasarlanması gerektiğini savundu. Tamamlanmış evlerin ve onların ayrı bileşenlerinin taşınabilirliği, Prouvé un tüm prefabrike evlerinin bir başka önemli yönüdür. Yerel yapı geleneklerini modernist materyaller ve tasarımlarla sentezleme konusundaki yenilikçi yaklaşımının bir başka örneği de 1958'de petrol endüstrisi çalışanları için tasarladığı evdir (Resim 5). Tasarım yeniliklerini teşvik eden bir girișimci olan Marie-Claire, bu projeyi finanse etti. Çölün sıcak kurak iklimi ve s1caklıktaki büyük günlük dalgalanmalar, malzemelerin ve tasarımın hem sıcak hem de soğuk havaların iklimsel etkisini en aza indirgemek zorunda olduğu anlamına geliyordu. Prouvé, Bedevi benzeri bir yaşam alanını klima gibi modern olanaklarla birleștirdi. Maison Tropicale'ye çok benzeyen evde, uyuma ve yaşam alanları için $16 \mathrm{~m}^{2}$ ve $28 \mathrm{~m}^{2}$ 'lik iki farklı modül kullandı. Bu konutlar nakliye koşullarının oldukça zor olduğu bölgelere kızaklarla ile taşınmıştı (URL-5).
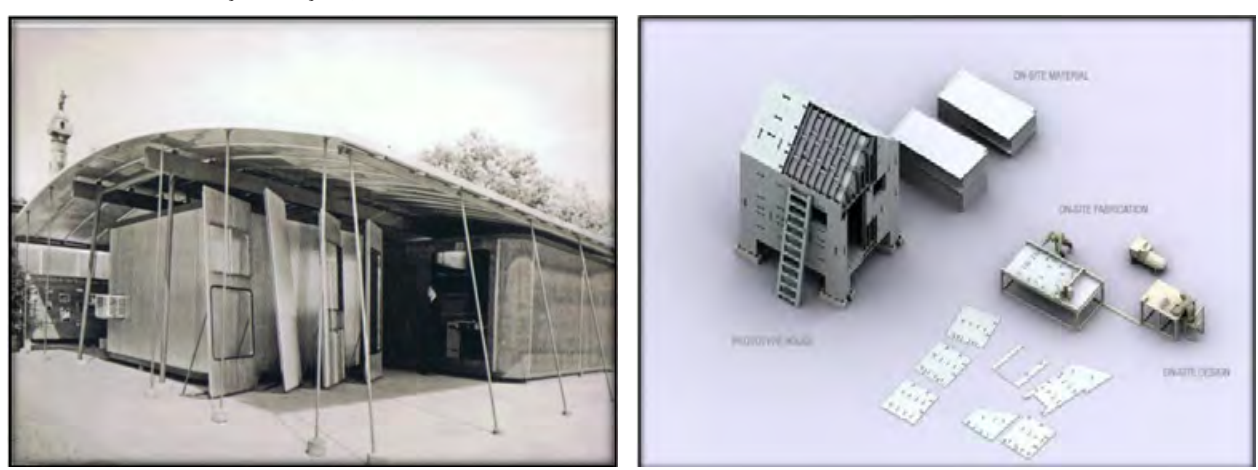

Resim: 3

Dymaxion House, Buckminster Fuller, 1929 (URL-2)

Resim: 4

Whichita Evi, Buckminter Fuller (URL-2)
Resim: 5

Maison du Sahara, SETAP and Co. Perriand mimarlık, Jean Prouve, 1958 (URL-5)

Resim: 6

Prouve'un SGA Evi (URL-8) 
Resim: 7

Plug in City, Archigram,1966 (URL-3)
Prouve daha sonra SGA Evi'ni (Resim 6), kurulum hızını en üst düzeye çıkarmak ve masrafları en aza indirgemek için vasıflı işgücüne olan ihtiyacı karşılamak için geliştirdi. Kurulum için gereken tek alet lastik bir çekiçti (URL-5). ABD'de yayınlanan Kentsel Konut Dergisi'nin düzenlediği konut tasarım projesinde ödül alan proje modül sistemlerin kullanımına yeni bir bakış açısı getirmiştir. Şantiye alanına dört ayrı kamyon ile nakledilen bitmiş oda bileşenleri radye temel üzerine yerleştirildi. Bina, farklı bileşenlerden oluşan bir ürün yelpazesi ile sayısız konfigürasyon olanağı sağlayacak şekilde tasarlanmıştır (M. Schoenborn, J., 2012).

Yirminci yüzyılın ikinci yarısında prefabrikasyonu, yüksek teknoloji-high tech hareketi etkiledi. Bu akımın öncü mimarları arasında, Michael Hopkins, Richard Rodgers ve Norman Foster yer alır. 1960'larda Peter Cook, Warren Chalk, Ron Herron, Dennis Crompton, Michael Webb ve David Greene'den oluşan Archigram, aslında bir propaganda ve pazarlama imgesiyle geleceğin manifestolarını yaratan bir mimarlık firmasıydı. Archigram grubu 1966 yılına kadar "Takılan Kent (Plug in City)" (Resim 7) ve "Kapsül Konut" tasarımları ile yaşayan kendi içinde sürekli büyüyebilen canlı organizma anlayışında projeler geliştirmişlerdir. Projelerinde iki önemli konu vardır: değiştirilebilir bölümler ve değiştirilemez bölümlerin tasarımı. Değiş̧tirilemez bölümler sabittir bir değişiklik yapılamaz sadece onarımlar gibi küçük müdahaleler söz konusudur. Değiștirilebilir bölümler ise tamamen sökülüp yerine yenisi takılabilir değiştirilen bölüm başka amaçla başka yerde tekrar kullanılabilir (Resim 8) (Cook P., Chalk W., Crompton D., Greene D., Ron Herron, Mike Web, 1999).
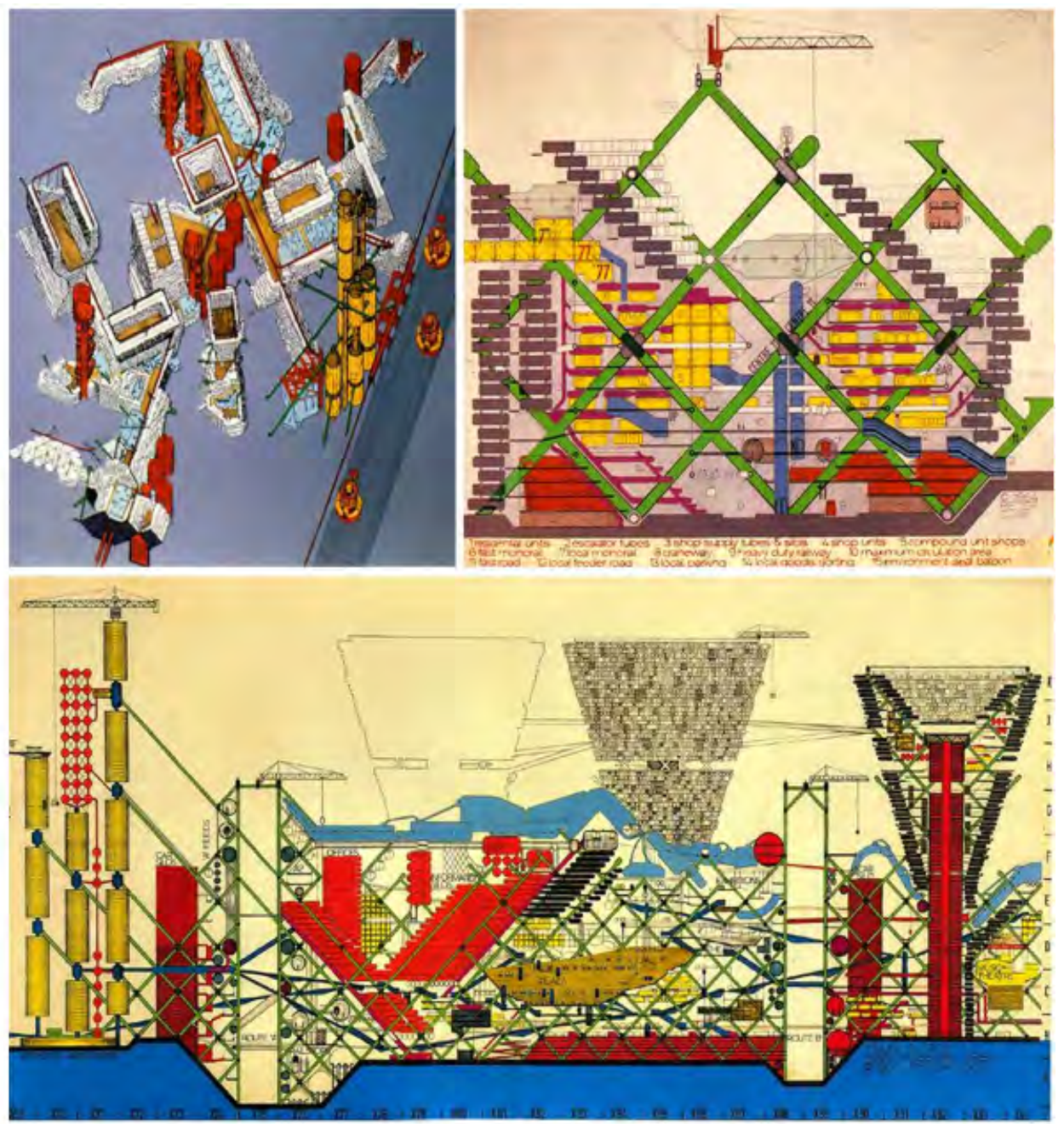


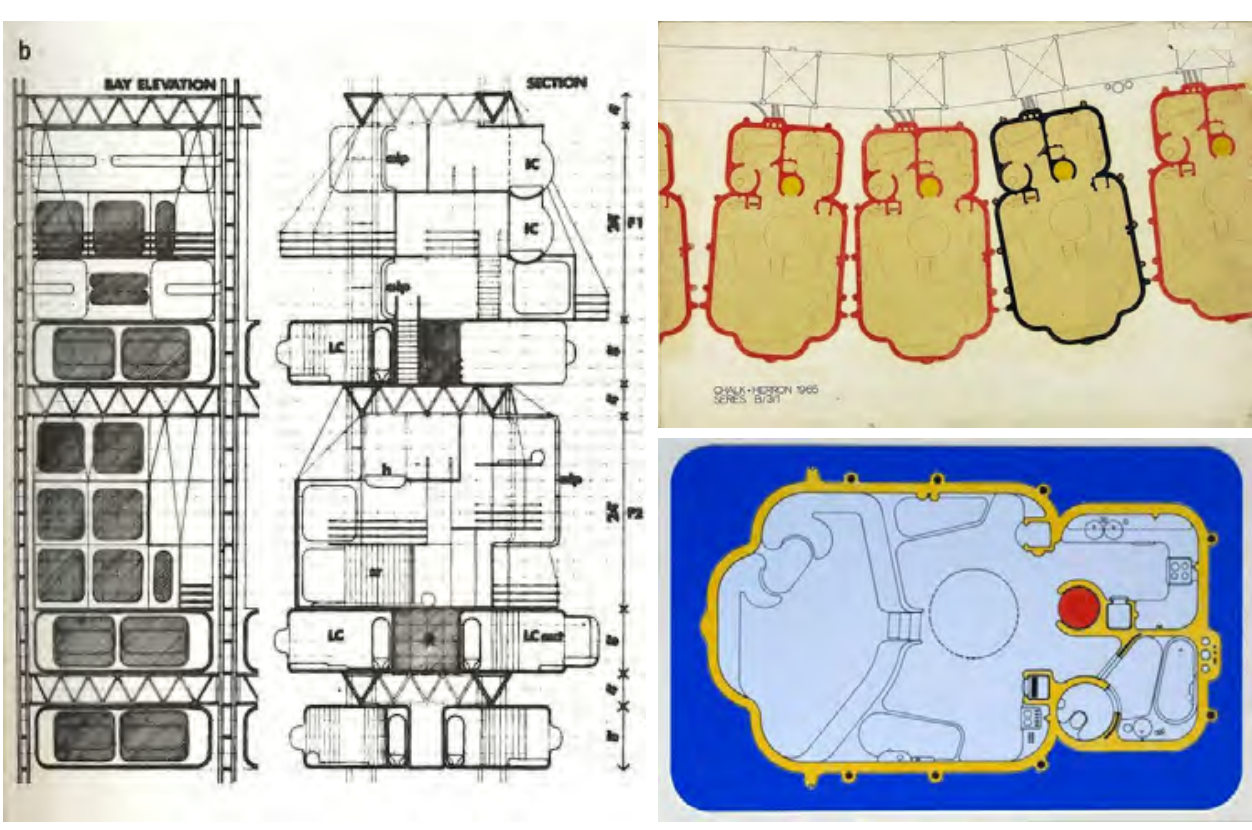

Ron Herron 1965 'de tasarladığı Kapsül Pier'de Plug in City projesi gibi değiştirilebilir ve büyüyebilmeye imkan veren modüllerden yapılmış canlı bir oranizma gibi şartlara uyum sağlama esasına göre yapılandırılmıştır (Resim 9).

1960'larda Safdie ve Rudoloph gibi Japon Metabolistler projelerinde modüler sistemleri yapısal ve servis çekirdeğine takarak kullandılar. Bu projelerin en ünlüsü, 1972'de Kurokawa'nın Nakagin Kapsül Kulesi'dir. Kurokawa, kiracıların taşınması veya modülün yenilenmesi gerektiğginde fişin takılı prizden çıkarılması gibi modüllerinde yerinden kolayca çıkarılabileceğine inanıyordu. Proje başlangıçta işten sonra eve gidemeyen veya evlerini az kullanan işçiler için bir otel olarak tasarlandı. Kapsüller tamamen modern tesislerde üretildi. İronik olarak, bina şimdiye kadar hiç değiştirilmemiş ya da çekirdekten çıkarılmamış modülleri ile önemli ölçüde bakıma ihtiyaç durumdadır. Geleneksel sistemlere göre çekirdeğin büyüklüğü sistemlerin takılmasındaki zorluklar proje maliyetini önemli ölçüde arttırmıştı (Resim 10) (URL-4).

1967 Dünya Fuarı'nda, Moshie Safdie, 24 yaşında ilk inşa edilen projesi olan 354 modüler üniteden 158 konutu içeren kompleksi tasarladı (Resim 11; Şekil 2). Betonarme prefabrike beton olarak 18 tip modül vardı. Modüller birbiri üzerine istiflenmiş, aralarında boşluklar açık bahçeler ve teraslar oluşturulmuştu. Modüller kolayca kurulacak veya taşınacak kadar hafif değildi, çok fazla varyasyona sahipti. Saha dışı zorluklara ek olarak yerinde çalışma, büyük vinçleri ve modülleri birbirine bağlamak için yoğun iş gücü gerekdi. $\mathrm{O}$

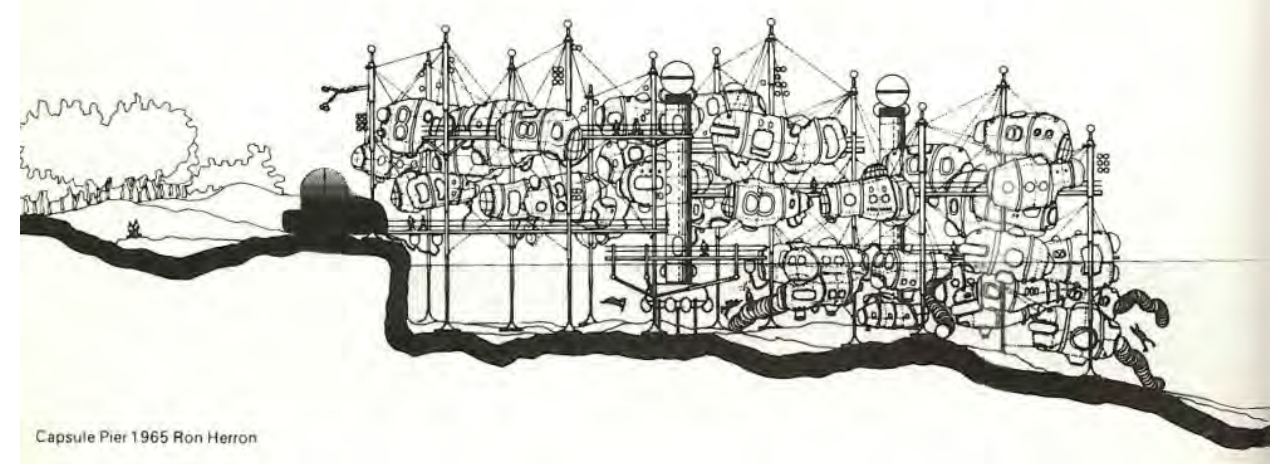

Resim: 8

Kapsül Konut, Archigram (Cook P., Chalk W., Crompton D., Greene D., Ron Herron, Mike Web,1999)
Resim: 9

Kapsül Pier, 1965, Ron Herron (Cook P., Chalk W., Crompton D., Greene D., Ron Herron, Mike Web, 1999) 
Resim: 10

Nakagin Kapsül Kulesi, Kisho Kurokawa, Tokyo, 1972 (URL-9)

Resim: II

Habitat Konutları, Moshie Safdie, Montreal, 1967 (URL-I2)

Şekil: $2 a$

Yapının kesiti (URL-13)

Sekil: $\mathbf{2 b}$

Yapinin planı (URL-13)

Şekil: 3

Lloyds Binası plan şeması (URL-I4)
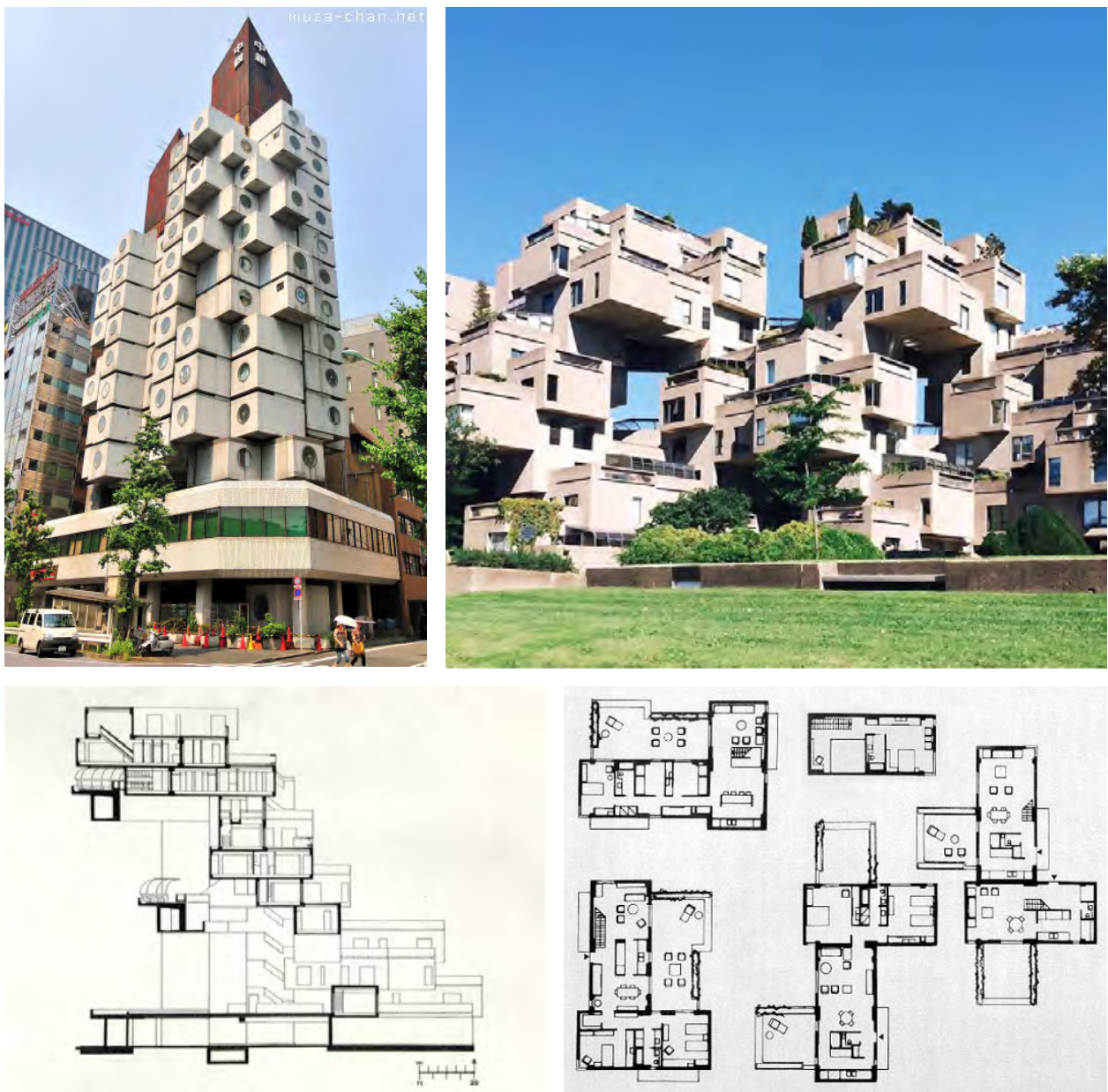

dönem için bu tak-çıkar konsepti pek tutulmadı ve Safdie, prefabrikasyon hayalini bıraktı, deneyini bir başarısızlık olarak nitelendirdi ve o sırada mimarlıkta prefabrikasyonun imkansız olduğunu iddia etti (URL-10;URL-11;URL-12; URL-22).

1982'de Richard Rogers'1n Londra'daki “Lloyd's of London” (Resim 12-13; Şekil 3) ve 1984'de Norman Foster'ın “Hong Kong Bank" çok katlı projelerinde (Resim 14; Şekil 4) 1slak hacimler modüller şeklinde uygulanarak yapım süresi önemli oranda kısaltılmıştır. Öyle ki Lloyds Binası Londra'nın kalbi sayılan bankalar bölgesinde çok dar bir cadde üzerinde bulunur. Bu bölgede çalışanların işlerini aksatmamaları için gece çalışmalar devam etmiş, servis kulesindeki 33 adet wc ünitesi bir gecede getirilip yerine takılmıştır.

1983 'te modüler yapım sistemlerini yapı endüstrisine tanıtmak amacı ile uluslararası

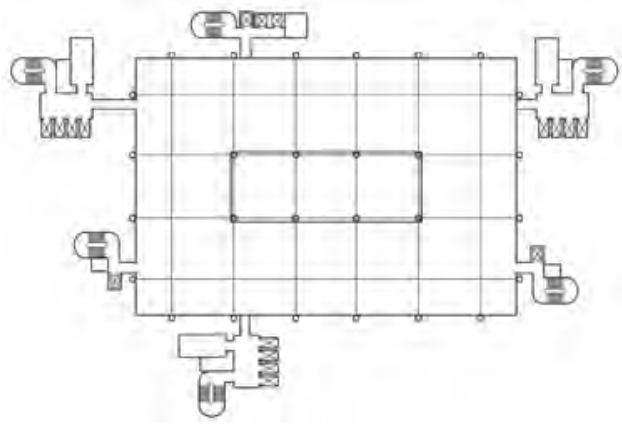
bir kuruluş olan The Modular Building Institute (MBI) kurulmuștur. Enstitü yaptığı çalışmalar, bilimsel toplantılar ve yayınlar ile modüler yapım sistemlerini üreticilere ve kullanıcılara tanıtarak yeni uygulamaları sektör ile paylaşmakta ve sistemin gelişimine katkı sağlamaktadır. Bu kuruluşun sistemi tanıtması ile birlikte estetik açıdan oldukça farklı tasarımlar ve projeler mimarlık gündemine gelmeye başladı. 

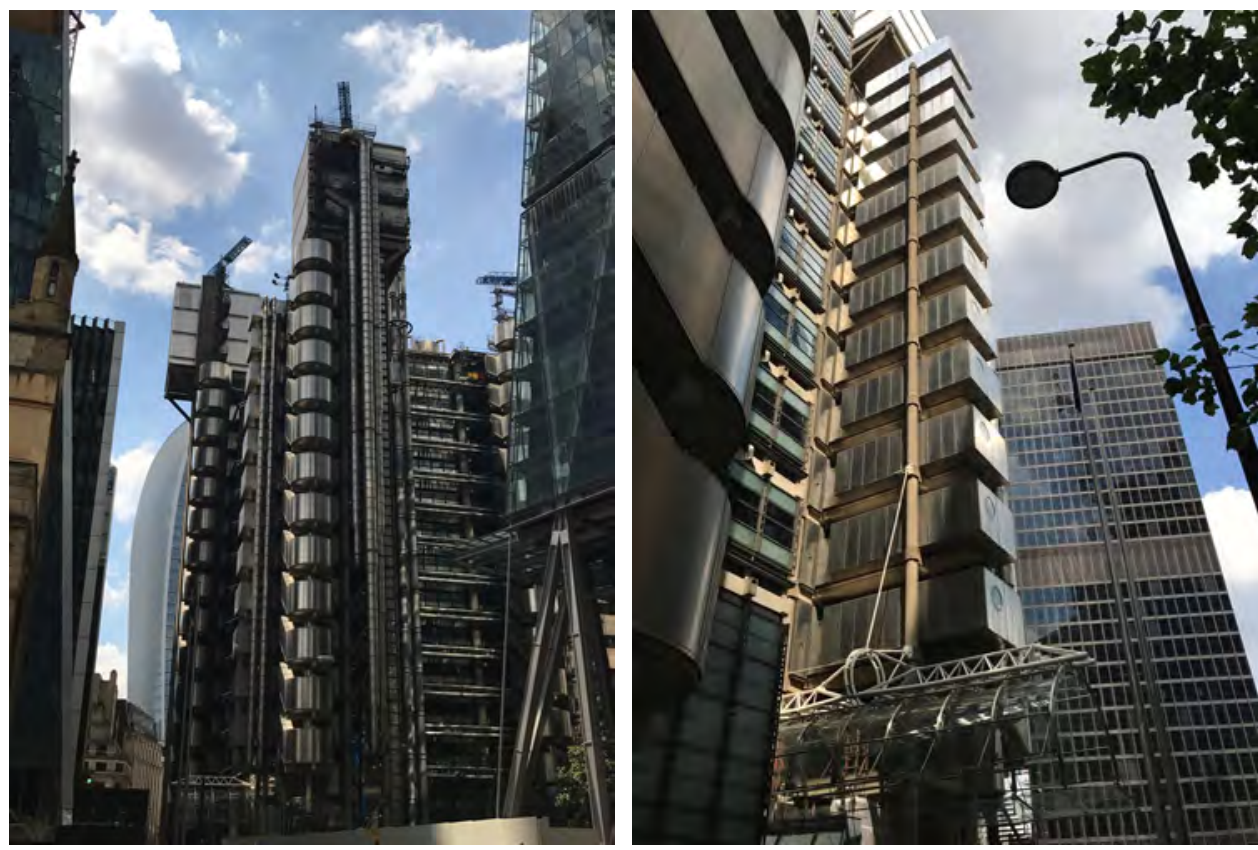

1990 yılında Joe Tanney “Çözünürlük 4" ismini verdiği ekibi ile birlikte kentsel konular üzerinde çalışmaya başladı. Firmanın modüler yapım sistemi konularındaki öncülüğü, 2002 yılında, Tanney'in standartlaştırılmış bir sistem içinde değişkenlik olasılığını değerlendiren birleştirilmiş ev tipleri geliştirmesiyle başlar. Tüm sistemlerin en iyi sonuçlarına ulaşan Tanney, "modern modüler seri" fikrini geliştirdi. Bu, modüler tipolojilerin, satın alınabilir kitler veya paketler olarak değil, tasarlanan sistem içinde neler yapılabileceğine dair kavramlar olarak geliştirdiği bir tasarım sürecidir (Şekil 5,6; Resim 15) (Smith,R., 2010).

2000 'lerde hafif çelik modüler kutu sistemler gerek uygulama projelerinde gerekse yarışma projelerinde, bilimsel makalelerde verimliliği üzerinde yapılan araştırmalarla mimarlık dünyasında ki gelişim sürecini devam ettirmektedir.

\section{Hafif Çelik İskeletli Modüler Kutu Yapım Sisteminin Tercih Edilme Nedenleri}

Modüler yapılar, mekanları oluşturan bölümler, veya tamamen bir mekan olabilen oda, servis üniteleri (tuvalet, asansör vb), ince yapı işlerinin tamamen veya bir bölümü dahil ol-
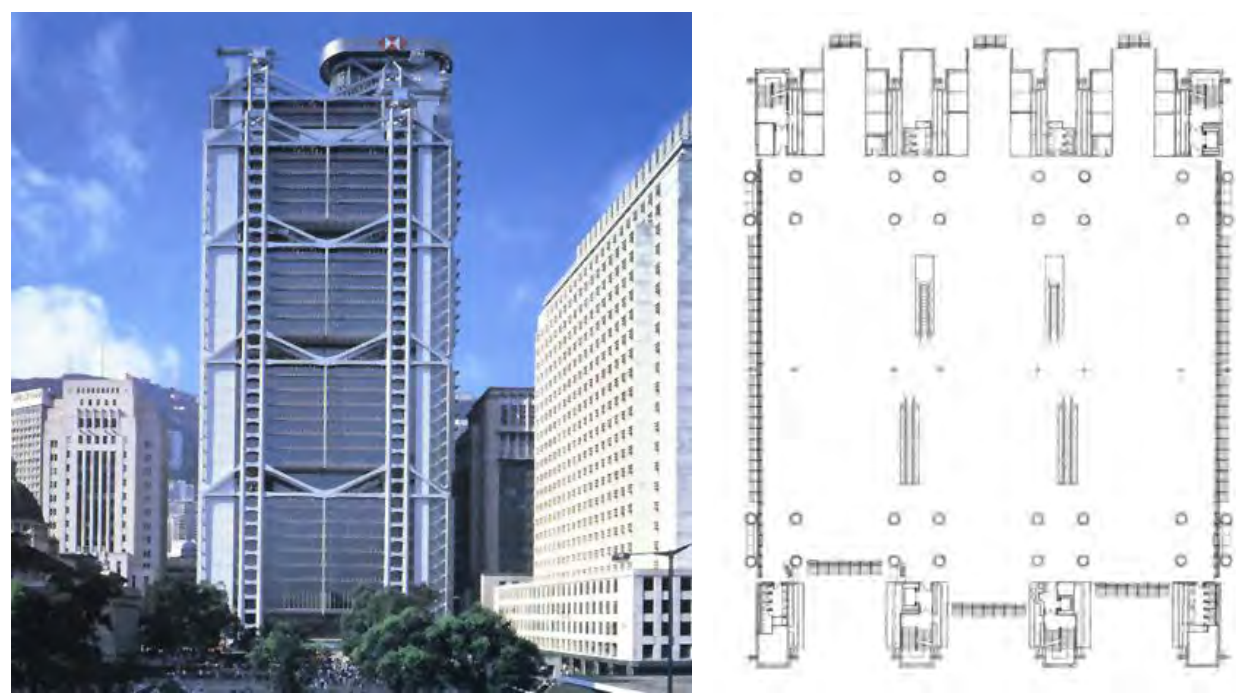

Resim: 12, 13

Lloyd Binasi, Richard Rogers, Londra, 1982 (Foto:Özlem Eren)
Resim: 14

Hong Kong bank, Norman Foster, Hong Kong, 1984 (URL-14)

Şekil: 4

Hong Kong Bankası planı (URL-15) 
Şekil 5-6; Resim 15:

çözünürlük: 4 ekibi konut için herhangi bir tasarıma uyarlanabilen modüller kullanir. Burada firmanın ürettiği sayısısz seşenekten sadece 35 tanesi verilmiştir (Smith, R., 2010)
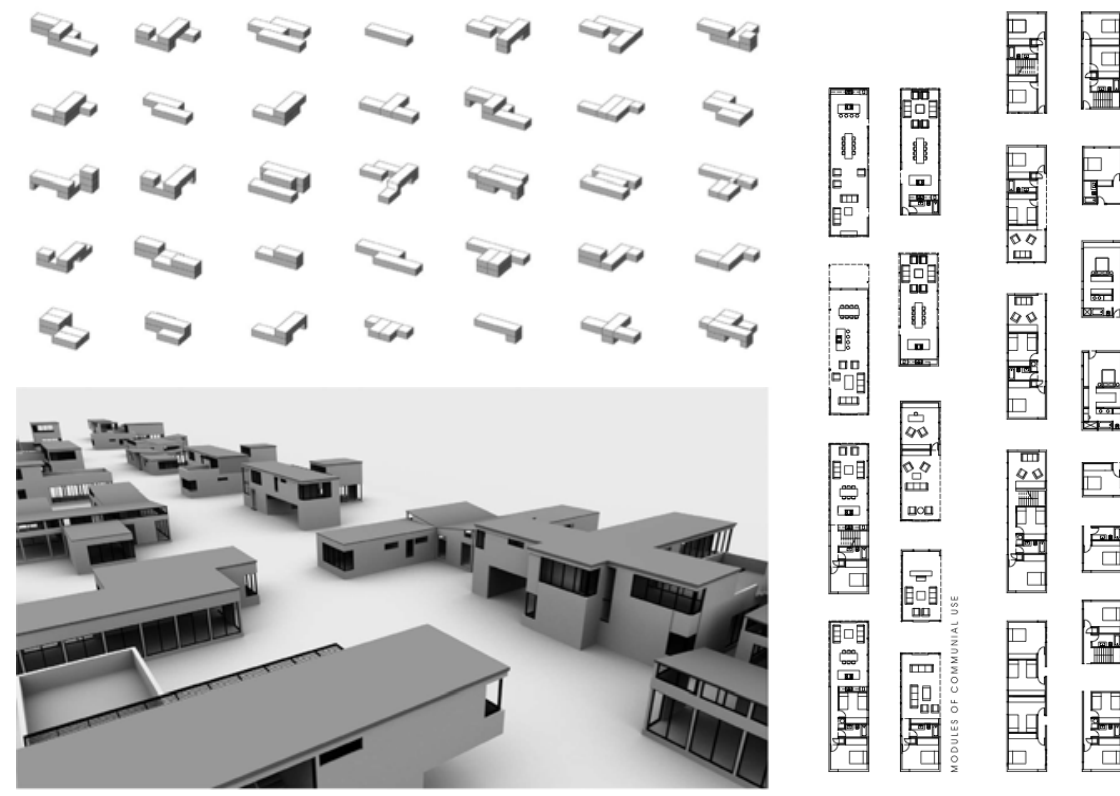

目

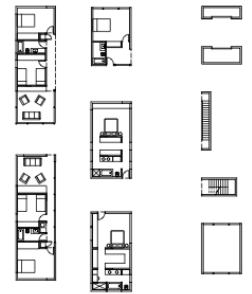

四

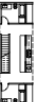
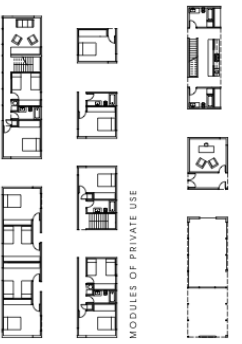

mak üzere fabrikada üretilmiş, şantiye alanına getirildiğinde sadece ait oldukları yerlere montajlarının yapıldığı ileri düzeyde bitmiş endüstriyel sistemler olarak tanımlanırlar. Modüller inşa edilecekleri arsaya taşınmadan önce kanalizasyon, temiz su, elektrik gibi tüm alt yapı hizmetleri tamamlanmış olduğu için, montaj işleminden sonra servisler hemen devreye girmektedir. Bu nedenle konut yerleşim alanları İmar planlarında belirlendikten sonra bu hizmetlerin getirildiği her yerde bu sistemi uygulamak oldukça kolaydır. Her sistemin kendi içinde tercih edilme nedenleri vardır (Eren, Ö., 2014; Smith,R., 2010; Herbert, 1978, URL-17). Modüler kutu sistemlerin tercih edilme nedenleri aşağıdaki şekilde sıralanabilir (Tablo 1).

Modül kutu sistemler, geleneksel yapım sistemleri ile karşılaştırıldığgnda şaniteyede meydana gelebilecek hertürlü yaralanma olasılığını azaltır ayrıca yine geleneksel sistemlerde yapı işçileri genel olarak yüksek seviyelerde gürültüye, toz ve hava ile taşınan partiküllere, olumsuz hava koşullarına, dolayısıyla verimliliği ve üretimi düşüren diğer faktörlere maruz kalır. Modüler yapım tekniği ile yapı işçileri bu olumsuz olaylara maruz kalmazlar. Modüler kutu sistemlerin bir diğer avantajı şantiye kulübeleri ve diğer tesislerin kiralanmasını kapsayan şantiye ön hazırlıklarının azaltılmasıdır. Genel olarak şantiye ön hazırlıkları toplam inşaat maliyetinin \%8 ila 15'ini teşkil etmektedir. Bu nedenle, şantiyedeki sürede \%50 azaltma sağlanması, ön hazırlıklarda orantılı bir tasarruf elde edilmesini sağlamaktadır (Lawson, M., Ogden, R., Goodier, C., 2014; URL-1).

Konut veya otel binasının erken tamamlanması sonucunda oluşan artan gelir ve azalan faiz masrafları, inşaat programına bağlı olarak ilgili hafta sayısı dikkate alınarak hesaplanabilir. Orta ölçekli bir otelde 45 haftalık inşaat sürecinde 20 haftalık tasarruf sonucu elde edilen maliyet zaman tasarrufu, inşaat maliyetinin \%22'sine eşit oranda tasarrufun sağlandığını göstermektedir (Lawson, M., Ogden, R., Goodier, C., 2014). 2015'de Çin'de 57 katlı bir gökdelen 19 günde (Çağlar,S., 2017), ve 15 katlı Ark Otel Binası 360 saatte tamalanmıştır (URL-21). Bu iki yapınında bu kadar kısa sürede hizmete açılması modüler kutu sistemler ile gerçekleşebilmiştir.

Doğadaki inşa ve yıkım atıklarının etkisi çok büyüktür. ABD’de her yıl şantiye alanlarından 135 milyon tondan daha fazla atık, atık gömme alanlarına getirilmektedir. Bina yıkımlarında ise bu değerler çok ciddi bir şekilde kat ve kat artmaktadır. Modüler yapım şantiyede atık yönetimine doğrudan katkıda bulunması açısından kaynak verimlidir. 


\begin{tabular}{|c|c|c|c|}
\hline $\begin{array}{l}\text { Taşıyıcı Sistem ve } \\
\text { Tasarım Açısından }\end{array}$ & $\begin{array}{l}\text { Maliyet } \\
\text { Açısından }\end{array}$ & $\begin{array}{l}\text { Şantiyede Organizasyonu } \\
\text { ve İş Güvenliği Açısından }\end{array}$ & Çevre Açısından \\
\hline Hafif strüktür & $\begin{array}{l}\text { Şantiye içi } \\
\text { depolamaya olan } \\
\text { gereksinmelerde } \\
\text { azalma ve } \\
\text { malzemelerde } \\
\text { daha az kayıplar }\end{array}$ & $\begin{array}{l}\text { Geleneksel sistemlerde } \\
\text { meydana gelen iş } \\
\text { akışı sıralamasının } \\
\text { değiştirilmesinden dolayı } \\
\text { kaynaklanan çalışma } \\
\text { sürelerinin uzaması } \\
\text { ortadan kalkmakta, çalışma } \\
\text { saatlerinin düzenlenmesinde } \\
\text { daha az anlaşmazlıklar ve } \\
\text { ustaların daha iyi organize } \\
\text { edilmesi }\end{array}$ & $\begin{array}{l}\text { Prefabrikasyon ve ilgili } \\
\text { teknolojiler, şantiye dışı } \\
\text { bölgelerde daha yüksek } \\
\text { nakliye maliyetlerine ve enerji } \\
\text { harcamalarına neden olsalar } \\
\text { da, malzeme atığı, hava ve } \\
\text { su kirliliği, toz ve gürülttü ve } \\
\text { toplam enerji maliyetlerindeki } \\
\text { azalmalardan dolayı daha az } \\
\text { iş sahası ortamı etkileri ortaya } \\
\text { koyar. }\end{array}$ \\
\hline $\begin{array}{l}\text { Temel tasarımı } \\
\text { basitleştirildiği için } \\
\text { maliyetinden tasarruf } \\
\text { sağlanır }\end{array}$ & $\begin{array}{l}\text { Binanın erken } \\
\text { tamamlanarak } \\
\text { hizmete açılması } \\
\text { ile büyük } \\
\text { ekonomi sağlanır. } \\
\text { Kısa sürede } \\
\text { yapım. }\end{array}$ & $\begin{array}{l}\text { Güvenli sistemdir. } \\
\text { Şaniteyede meydana } \\
\text { gelebilecek hertürlü } \\
\text { yaralanma olasılığını } \\
\text { azaltır. }\end{array}$ & $\begin{array}{l}\text { Modüler kutu yapı, doğası } \\
\text { gereği, malzeme ve kaynak } \\
\text { tasarufludur. Modüler kutu } \\
\text { yapım yöntemi } \\
\text { montaj sırasında, nakliye } \\
\text { sırasında oluşacak malzeme } \\
\text { kayıplarının önüne geçilir }\end{array}$ \\
\hline $\begin{array}{l}\text { İhtiyaçlar gerektiğinde, } \\
\text { modüler binalar } \\
\text { sökülebilir ve yeni } \\
\text { modüller binaya } \\
\text { eklenebilir. }\end{array}$ & $\begin{array}{l}\text { Üretim hattı } \\
\text { işlemlerine daha } \\
\text { fazla yatırım } \\
\text { yapılması, } \\
\text { montaj hızının } \\
\text { artmasına ve } \\
\text { üretim verimliliği } \\
\text { sayesinde maliyet } \\
\text { tasarrufu elde } \\
\text { edilmesini } \\
\text { sağlamaktadır. }\end{array}$ & $\begin{array}{l}\text { Modüler ünitelerin } \\
\text { kurulumunda kısa } \\
\text { süreliğine kiralanabilen } \\
\text { vinçler kullanılabildiği için } \\
\text { vincin günlük olarak daha } \\
\text { az kullanımı ile tasarruf } \\
\text { yapılır. }\end{array}$ & $\begin{array}{l}\text { Modüler kutu yapı temel ve } \\
\text { diğer şantiye işleri ile birlikte eş } \\
\text { zamanlı olarak şantiye dışında } \\
\text { inşa edilir, bu nedenle şantiye } \\
\text { içinde gerek duyulan araçların } \\
\text { ve ekipman sayısını düşürdüğü } \\
\text { gibi, çevredeki iş ortamı } \\
\text { üzerindeki zamanı ve gürültü, } \\
\text { trafik vb etkileri de azaltır. }\end{array}$ \\
\hline $\begin{array}{l}\text { Fabrika ortamında } \\
\text { üretilmesinden dolayı } \\
\text { yüksek düzeyde } \\
\text { bitmişlik }\end{array}$ & $\begin{array}{l}\text { Katı Kalite } \\
\text { güvence } \\
\text { prosedürlerinin } \\
\text { uygulanması ile } \\
\text { ileride oluşacak } \\
\text { hataların } \\
\text { min düzeye } \\
\text { indirilmesi } \\
\text { ile yeniden } \\
\text { yapılan işçiliğin } \\
\text { önlenmesi } \\
\text { (Anon,2008). }\end{array}$ & $\begin{array}{l}\text { İnşaat programının süresi, } \\
\text { daha net bir şekilde } \\
\text { öngörülebilmektedir ve } \\
\text { şantiye işlemlerinin hava } \\
\text { şartlarına bağımlılığı daha } \\
\text { düşük seviyededir. }\end{array}$ & $\begin{array}{l}\text { Modüler kutu yapı, ürünleri } \\
\text { denetlenen üretim koşullarında } \\
\text { yapıldıkları için atık oluşumuna } \\
\text { karşı duyarlıdır ve şantiye } \\
\text { koşullarına göre dikkatli ve } \\
\text { stratejik bir şekilde teslim } \\
\text { edilmesi de nakliye sırasında } \\
\text { oluşabilecek malzeme } \\
\text { kayılarını azaltır. }\end{array}$ \\
\hline \multirow[t]{3}{*}{$\begin{array}{l}\text { Üretim kolaylığına } \\
\text { bağlı olarak detayların } \\
\text { test edilmesi ve } \\
\text { rasyonelleştirilmesi } \\
\text { vasıtasıyla tasarım } \\
\text { aşamasında geliştirme } \\
\text { daha ön plana } \\
\text { çıkabilmektedir } \\
\text { (Lawson, M., Ogden, } \\
\text { R., Goodier, C., 2014). }\end{array}$} & $\begin{array}{l}\text { Az sayıda işçi ile } \\
\text { yapılabilmesinin } \\
\text { getirdiği ekonomi }\end{array}$ & $\begin{array}{l}\text { Daha az şantiye çalışanı ve } \\
\text { dolayısıyla daha az sayıda } \\
\text { şantiye tesisi, vs. }\end{array}$ & \\
\hline & & $\begin{array}{l}\text { Hafif çelik modül kutu } \\
\text { sistemlerde yapı elemanları } \\
\text { ve bileşenlerinin ağırlığı } \\
\text { azalmış, bu da nakliye } \\
\text { işlerini ve montajı } \\
\text { kolaylaştırmaktadır. }\end{array}$ & \\
\hline & & $\begin{array}{l}\text { Şantiye kulübeleri ve diğer } \\
\text { tesislerin kiralanmasını } \\
\text { kapsayan şantiye ön } \\
\text { hazırlıklarının azaltılması. }\end{array}$ & \\
\hline
\end{tabular}

Tablo: I

Hafif Çelik Modül Sistemlerin Avantajları 
Tablo: 2

Hafif Çelik Modüler Kutu Sistemlerin Avantajları (Erturan, B. ve Eren, Ö., 2012)
İngiltere'de WRAP (Attk \& Kaynaklar Eylem Programı) tarafından yayımlanan bir rapora göre, şantiye dışı üretim yöntemlerini kullanmak, yapı endüstrisinde oluşacak atığı azaltmada yardımcı olabilir. Şantiye dişı üretim, zaman ve maliyet tahmini, sağlık, güvenlik ve uzmanlık bağlamlarında yapı endüstrisine faydalar sunmaktadır. Geleneksel yapımda en büyük atıklar, ambalajlar $\% 5$, ahșap $\% 25$ ve alçı paneller $\% 36$ paya sahiptir. Şantiye dışı imalatın ve modern yapım yöntemlerinin kullanımının arttırılmasıyla ahşap paletler, şrinkli ambalajlar, mukavvalar, alçı panel, ahşap, beton, tuğla ve çimento gibi atıkların azaltılması yoluyla \%90'a varan bir tasarruf sağlanabilir. Ayrıca, atık oluşumu daha az miktarda olduğu için inşaat malzemelerinin kullanımı ve yetersiz kalitedeki malzemelerin yeniden işlenmesi sonucunda oluşan atık gömme masrafları da azalmaktadır. Uygulanmış projelerden elde edilen deneyim, atık miktarının $\% 80$ oranında azaldığını göstermiştir ve bu oran, inşaat maliyetinin \%1-2'sine tekabül eden taşıma ve arazi gömme masraflarında da azalmaya işaret etmektedir. Ayrıca yine bu yöntem ile şantiye alanındaki hırsılıklardan dolayı meydana gelen malzeme kaybı ve montaj sırasında, nakliye sırasında oluşacak malzeme kayıplarının da önüne geçilir (URL-1).

Geleneksel yapım yöntemlerinde proje yönetimindeki hatalara bağlı olarak zaman, iş gücü, kaynaklarda kayıplar olabilmekte, veya malzeme ve ekipmanların doğru depolanmamasından dolayı işçilerin malzemelere ulaşması zorlaşmakta bu da zaman kaybına neden olmaktadır. Halbuki modüler kutu sistemlerinde bitmiş ürünün şantiyede sadece ait olduğu yere montajının yapılması bu olası sorunları ortadan kaldırır (M. Schoenborn, J., 2012).

\section{Hafif Çelik Modüller ile Tasarım}

Hafif çelik modüler kutuların taşıyıcı sistemi 1.0 ila 3.2 mm kalınlığındaki galvanize çelik şeritlerin soğukta şekil verilmesi yöntemi ile elde edilen profillerden kurulur. $\mathrm{Bu}$ kalınlıklardaki profillerden üretilen modül boyutları, aşağıda belirtilen etkenlere bağlı olarak belirlenir:

- Taşıma kolaylığ 1

- Şantiye konumu ve erişim

- Ahşap kaplama veya alçıpan dış yüzey kaplamaları gibi standart bileşen boyutları

Malzemenin verimli kullanılması için duvar dikme ve döşeme profillerinin belli aralıklarla yerleştirilmesi gereklidir. Bu nedenle $1.200 \mathrm{~mm}$ genişliğindeki alçı panel boyutlarına uyum sağlayan, $400 \mathrm{~mm}-600 \mathrm{~mm}$ ve $1200 \mathrm{~mm}$ 'lik yapısal bir ızgara sistemi kullanıld1ğında verimli sonuç elde edilir. Ekonomik taşıma sağlayabilmek için sıkça kullanılan maksimum genişlik 3.5 m'dir. Nakliye koşullarına bağlı olarak modüllerin uzunlukları 8m-12 m olabilirken, çok özel önlemler ve uygulamalar için $16 \mathrm{~m}$ uzunluğa kadar olan modüller de yapılabilmektedir(G. Staib, A. Dorrhofer, M. Rosenthal, 2008).

Hafif çelik modüler kutu sistemler kendi içerisinde taşınma prensiplerine göre, mekan özellikleri açısından ve kullanım şekline göre sınıflandırılır (Tablo 2).

\section{Taşınma Prensiplerine Göre Hafif Modüler Kutu Sistemlerin Sınıflandırılması}

Hafif çelik modül kutu sistemler taşınma prensiplerine göre incelendiğinde modüller, taşıyıcı ve taşınan olmak üzere iki şekilde sinıflandırılır (Şekil 7).

\begin{tabular}{ll}
\hline Modüllerin Sınıflandırılması & Sistem Türü \\
\hline Taşınma Prensiplerine Göre & Taşıyıcı Modüller \\
\cline { 2 - 2 } & Taşınan Modüller \\
\hline Bitmişlik ve Mekan Özelliklerine Göre & Kapalı \\
\cline { 2 - 2 } & Açık \\
\cline { 2 - 2 } & Yarı Açık \\
\hline Kullanım Şekline Göre & Yaşama Mekanları \\
\cline { 2 - 2 } & Tesisat Hacimleri \\
\hline
\end{tabular}




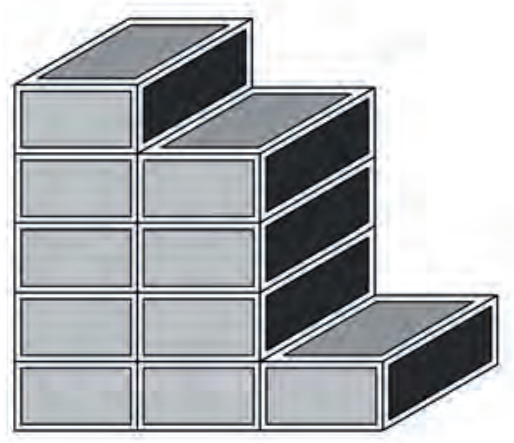

A

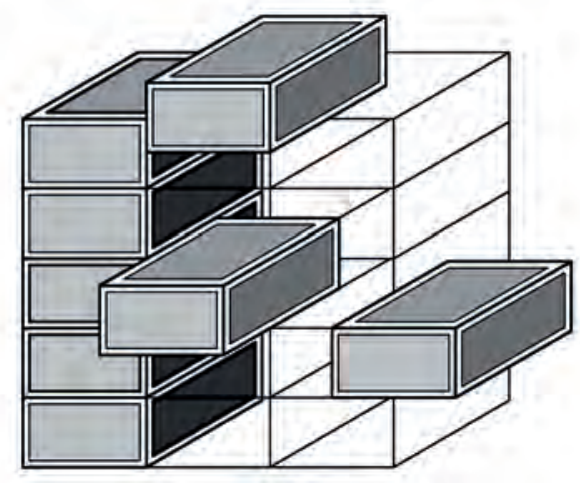

$\mathrm{B}$
Şekil: 7

Modüllerin taşıtılma prensipleri A)yığma sistem, B) iskelet sisteme taşıtılması (Detail 1974/2,5.216)

\section{Taşıyıcı Modüler Kutu Sistemler}

Taşıyıcı modüller, kendi yüklerini taşımalarının yanı sıra üzerlerine gelen yükleri de karşılayarak taşıyıcı strüktürün bir parçası olarak görev almaktadır. Bu sayede modüller, taşııı bir iskelete gereksinim olmadan yığma yapı yöntemi ile düzenlenebilmektedir. Statik nedenlerden dolayı bir sınırlama mevcut olduğundan çok fazla yüksek istiflemeler mümkün değildir. Habitat Konutlarını oluşturan modüller birbiri üzerine oturtularak taşınan yığma prensip esasına göre yapılmıştır (Şekil 7-8) (Zainal Abidin, A.R.B., 2007).

KieranTimberlake Washington, D.C. bölgesinde üç katlı Sidwell Friends Orta Okulunun yenileme projesinde kendi

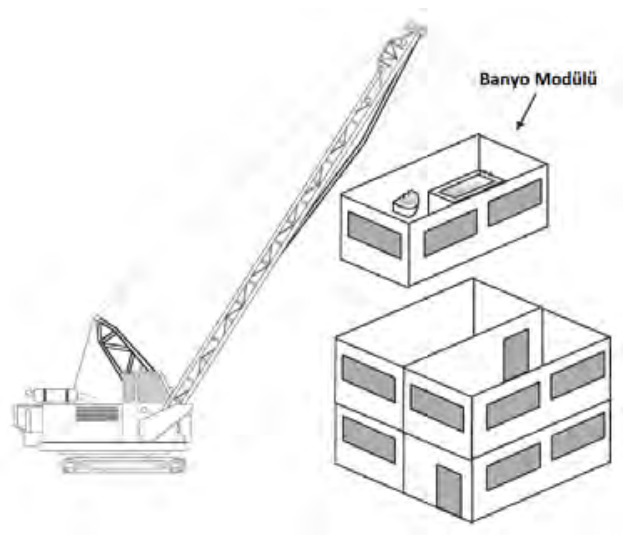

Şekil: 8

Taşıyı ı modüllerin birbiri üzerine yerleşimi (Emmit, S., ve Gorse, C.,2010) kendini taşıyan yığma yapı taşıyıcı sistem prensiplerini uygulad1 (Resim 16-17) (Smith, 2010).Resim 16-17.

İngiltere'de Murray Grove Apartman yapısı fabrikada üretilen modüllerin şantiyeye nakledilmesi ile 2 hafta gibi kısa bir sürede inşa edilmiştir. Toplam 32 daire içeren yapıda tek odalı ve iki odalı olmak üzere iki farklı plan tipi vardır. Toplam 74 modül kullanılan yapıda tek odalı daireler 2 modülden, iki yatak odalı daireler 3 modülden yapılmıştır (Resim 18-19; Şekil 9-10-11). L formunda ki planın kollarının kesişiminde sirkülasyon kulesi yükselir. Modülleri kaldırmak için vinç avluya yerleştirilerek caddeyi kullananlar rahatsız edilmemiştir. Caddeye ve iç avluya bakan cephelerde balkonlar yer alır (URL-18).

\section{Taşınan Modüler Kutu Sistemler}

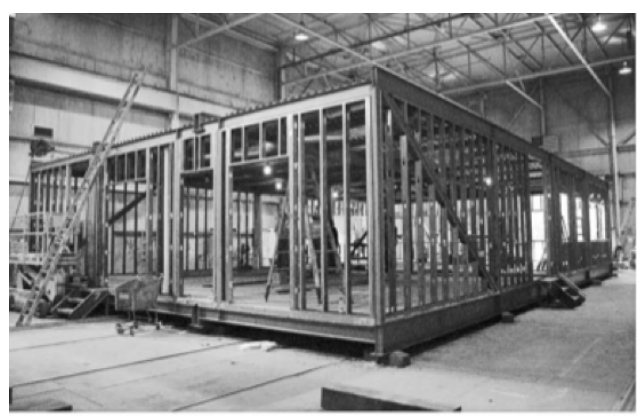

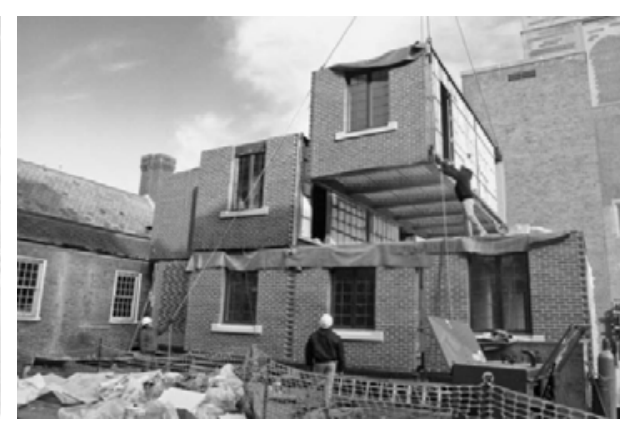

Resim: 16, 17

Hafif çelik modül sistemli sidwell Friends orta Okulu, KieranTimberlake (Smith, 2010) 
Resim: 18

Murray Grove Apartmanı (URL-18D)

Resim: 19

Modüllerin yı̆̆ma yapı prensiplerine göre yerleşimi (URL-I8D)
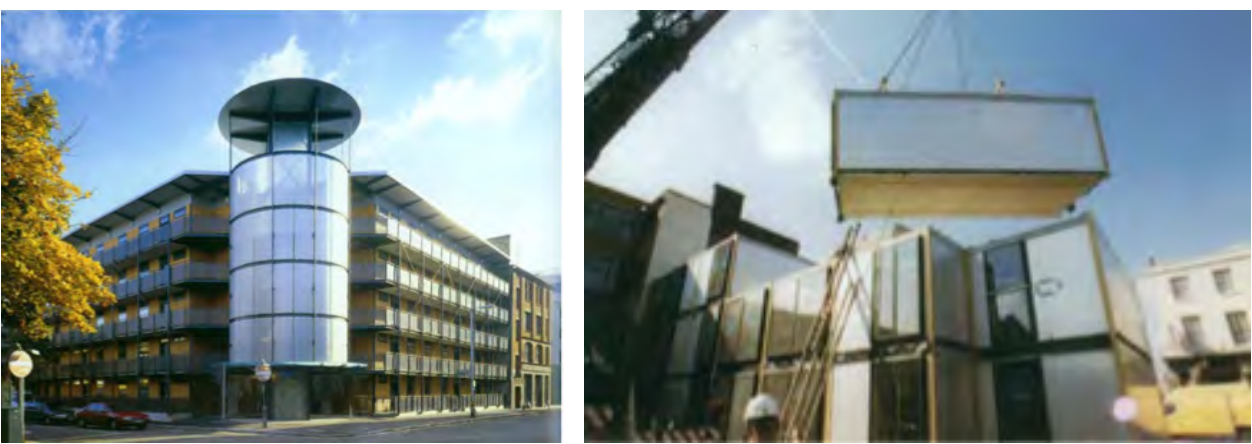

Şekil: 9

Murray Grove Apartmanı (URL-18) Şekil: 10

3 modülden oluşan 2 yatak odalı daire (URL-18)

Şekil: II

Bina modüllerinin yerleşim aşamaları (URL-18)
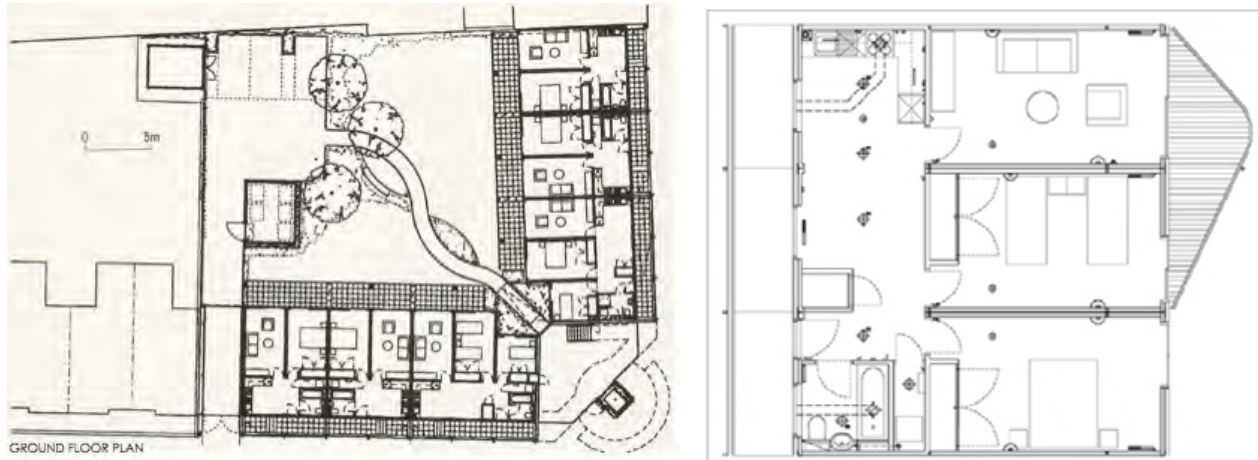

Modüller birbirlerini taşımazlar, çekmece sistemi gibi bir taşıyıcı iskeletin içine sürülür veya asılır. Taşınan modüller, yalnızca kendi yüklerini taşımakta ve sisteme etki eden diğer kuvvetlerin karşılanmasında görev almamaktadır. Taşıyıcılık özelliği bulunmayan bu modüller ile bir yapı oluşturulmak istendiğinde, taşıyıcı bir iskelete ya da rijit bir askıya ihtiyaç duyulmaktadır. Modüler kutu sistem geliştiricileri, modüler kutu sistemli yapıların taşınır olduğu, yani kendi modülünüzü, kendiniz bir taşıyıcı iskeletin içine yerleştirip
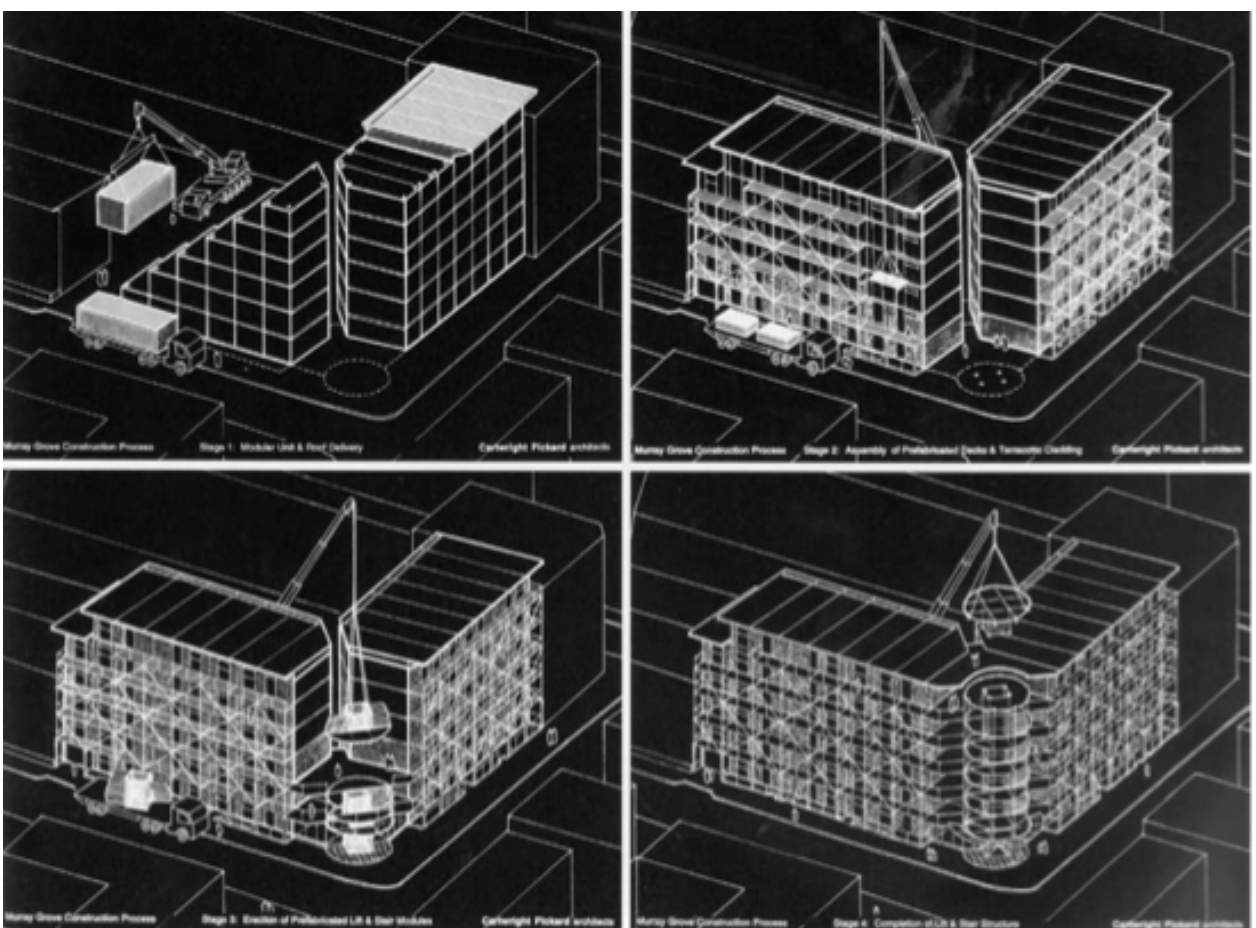

Sayı 26, Aralık 2018 
tekrar çıkarmanın, dolayısıyla yer değiştirirken başka bir yerde orada kurulan bir taşıyıcı iskelete asılmak üzere teçhizat da dâhil komple binayı bile götürmenin mümkün olduğunu savunurlar (Şekil 12) (Detail 1974/2,s.216; Erturan, B. ve Eren, Ö., 2012).

Berlin'de $11.000 \mathrm{~m}^{2}$ 'lik alanda inşa edilen Frankıe \& Johny öğrenci yurdu $12.19 \mathrm{~m}$ x $2.44 \mathrm{~m}$ boyutundaki 400 adet çelik modülün çelik iskelet içine yerleștirilmesi ile yapılmıştır. Farklı renklerdeki bu modüllerin, birbiri üzerinde kaydırılarak ve 90 derece döndürülerek tasarlanması, pen-

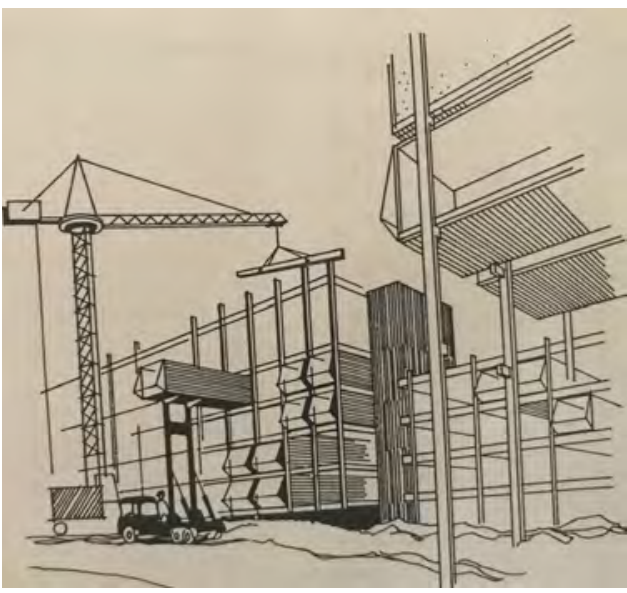
cere boşluklarının farklı yerlere gelmesi ile daha dinamik cephe çözümüne ulaşılmıştır. Dar olan modüllerin birleştirilmesi ile 235 adet $26 \mathrm{~m}^{2}$ 'lik tek kişilik, 65 adet $52 \mathrm{~m}^{2}$ 'lik iki kişilik ve 11 adet $78 \mathrm{~m}^{2}$ lik üç kişilik daireler tasarlanmıştır (URL-15) (Resim 22-23; Şekil 13-14)
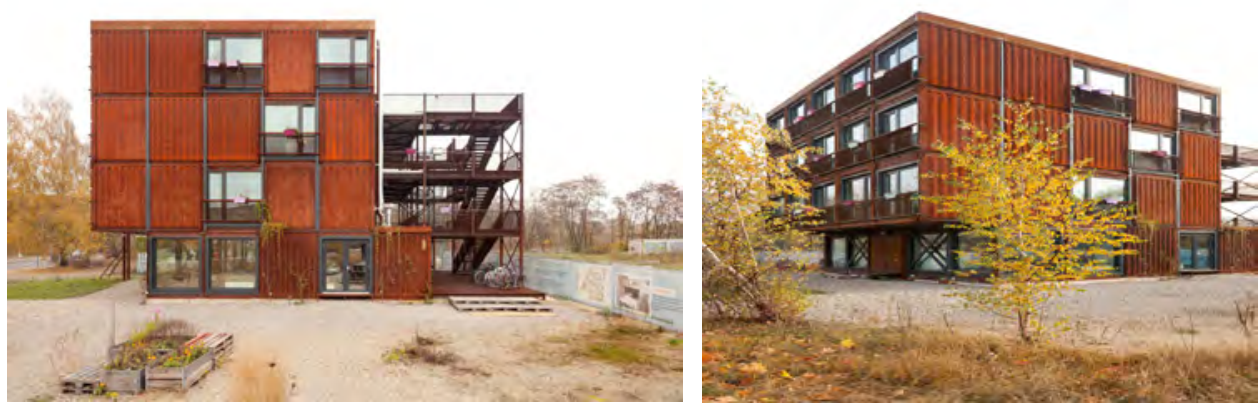

Hafif çelik modüler kutu üniteler bitmişlik ve mekan özellikleri açısından; kapalı, açık ve yarı açık modüller (Şekil 17) olmak üzere üç farklı şekilde sınıflandırılmaktadır.

Kapalı modül kutu sistemde, modüler kutuların her tarafı sınırlandırılarak mekan boyutları belirlenmiş olduğundan bu modüllerin gelişme olanağı yoktur (Şekil 17). Bu nedenle bu modüller ile yapılan yapılarda planlama esnekliği bulunmamaktadır. Genellikle oteller,
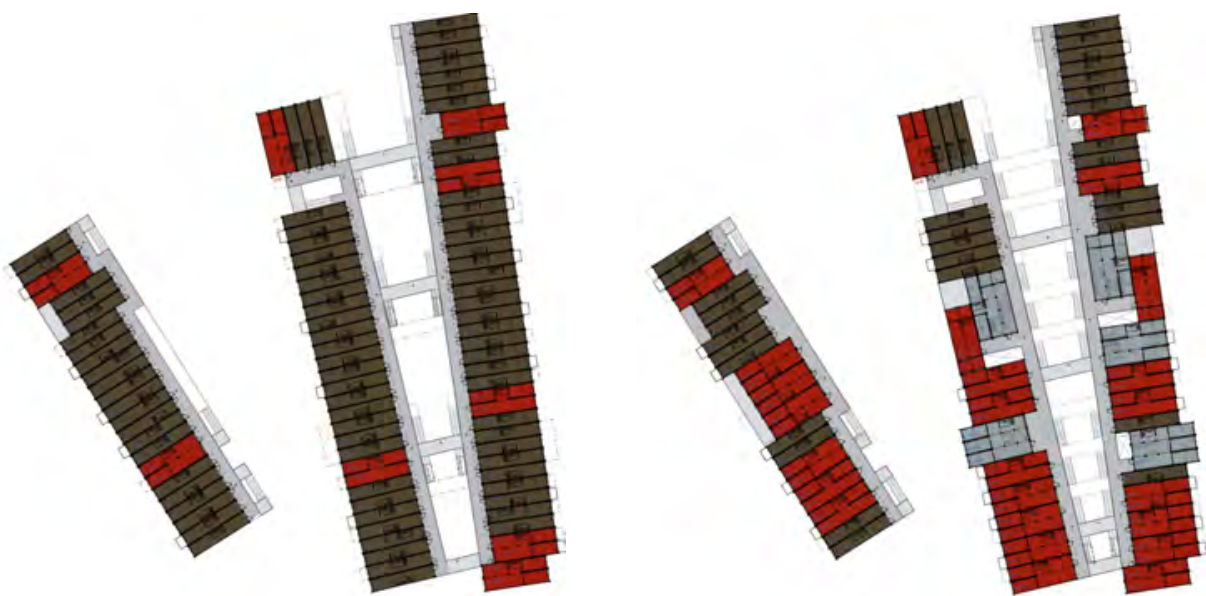

Sekil: 12

Modüllerin iskelet sistemin içine yerleştirilişi (Detail 1974/2,5.218))

Resim: 20-2I

Frankı \& Johny öğrenci yurdu, Berlin (URL-15)

Şekil: 13,14

Frankıe \& Johny öğrenci yurdu plan semaları, zemin kat ve üst kat planları. Tek, iki ve ü̧ kişilik odalar farklı renklerle gösterilmiştir (URL-15)) 


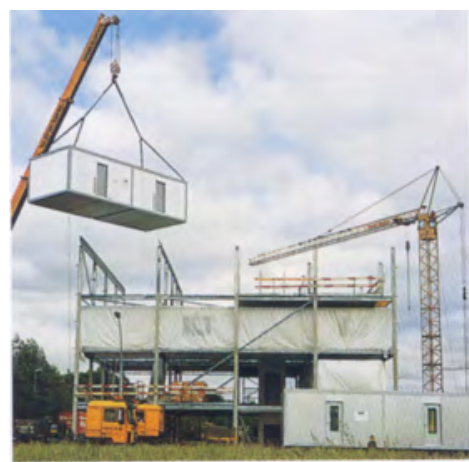

Resim: 22, 23, 24

Fellbach ofis binasi, Almanya (Detail, 2001))

Sekil 15:

Fellbach ofis binasinin kat planları (Detail, 2001)

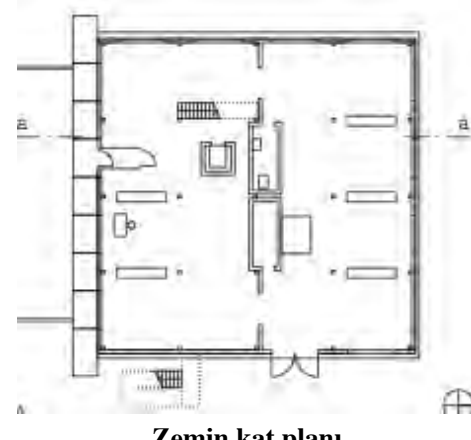

Zemin kat planı

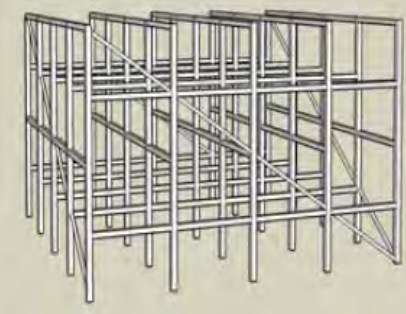

Şekil: 16

Bina konstrüksiyonunun kurulum aşamaları (URL-19)

Sekil: 17

Modül kutu f̧eşitleri a)Kapalı modül, b)Açık modül, c) Yarı açık modül (Eşsiz Ö., Koman l. 2007; Detail 1974/2 )
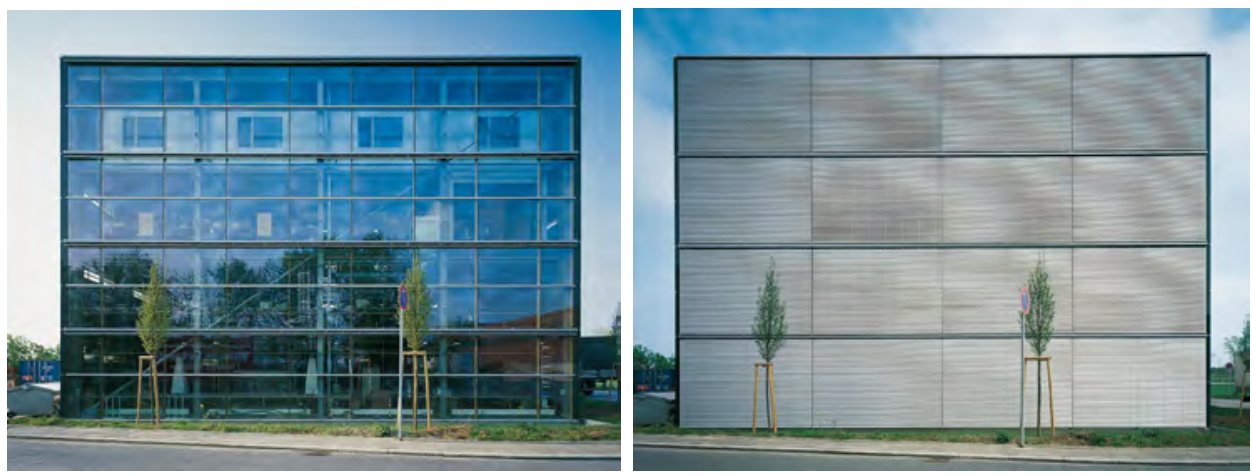

öğrenci yurtları, konutlar ve işçi konaklaması amaçlı kullanılan binalar için uygundur. Üst ve alt modülün duvarlarının üst üste gelecek şekilde yerleştirilmesi yük akışının zemine sürekli aktarımı açısından önemlidir. Genişlikleri, taşıma gerekliliklerinden ötürü yaklaşık olarak $4 \mathrm{~m}$ ile sınırlıdır (pek çok uygulamada 3m-3.6 m ölçüsü, tipik iç modül genişliğidir). Modül uzunluğu ise tipik olarak $6 \mathrm{~m}$ ila $10 \mathrm{~m}$ arasında değişmektedir. Hafif çelik duvarlarda 65 mm- 100 mm derinliğinde C kesitler kullanılmaktadır. Döşeme kirişleri, 150 mm- 200 $\mathrm{mm}$ arasında derinliğe, birleşik döşeme ve tavan derinliği ise $300 \mathrm{~mm}-450 \mathrm{~mm}$ arasında değişmektedir. Kaldırma ve stabiliteyi arttırma amaçlı modüllerin girintili köşelerinde ilave çelik profiller kullanılabilir (Lawson, M., Ogden, R., Goodier, C., 2014; Bock, T., 2006-5,).

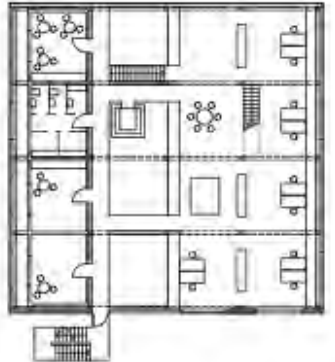

1.kat planı

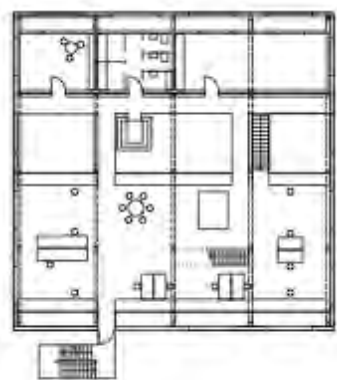

2.kat plan

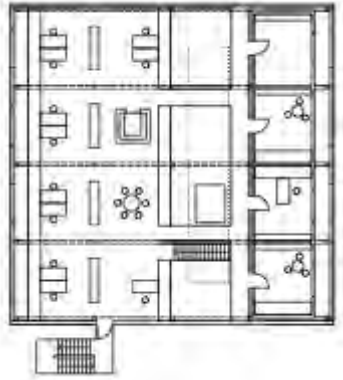

3.kat planı
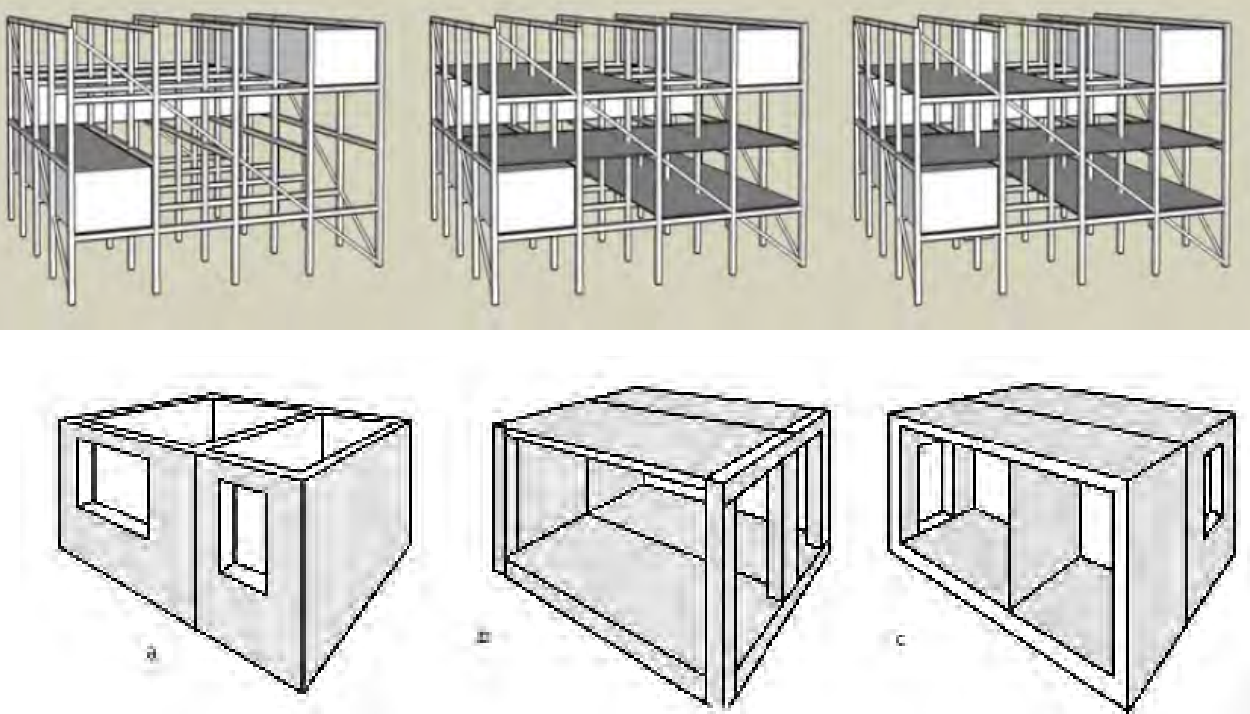

Sayı 26, Aralık 2018 
Açık modüler kutu sistemde, modüller, yüklerin köşe dikmelere aktarımı ile dört kenarı tamamen açık kenarlı tasarlanabilir (Şekil 17). Modüllerin açık olan tarafı yanına gelen modül ile birleştiğinde daha büyük mekanlar elde edilebilir. $7.2 \mathrm{~m}$ aralıklı kolon yerleşimi zeminde otopark düşünülmesi durumunda uygundur. Plan biçimlendirme serbestliği enine yöndedir. Açık modüllerde paralel başlıklı kirişlerin boyutları diğer modüllerdeki kirişlerden daha yüksektir. Açık modüllerin stabilitesinin sağlanması için çapraz elemanlar kullanılmalıdır. Diğer sistemlere göre yük taşıma kapasitesinin daha zayıf olması ne-

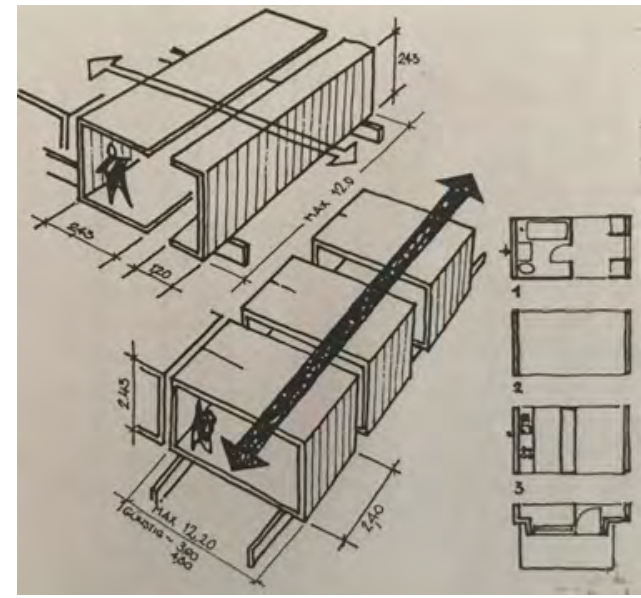
deni ile üç kattan yüksek yapılmamalıdır. Bu modüllerde servislerin içinden geçmesine izin verecek şekilde kirişler boşluklu yapılabilir. Köşelerde kullanılan kolonların boyutları SHS 70x70-100x100 arasında değişir (Lawson, M., Ogden, R., Goodier, C., 2014).

Yarı açık modüler kutular ise, kısa veya uzun kenarlarının açık bırakılması ile modüllerin birleştirildiği doğrultuya göre esnek mekanlar elde edilmesi amaçlanır (Şekil 18). Modüllerin stabilitesi, kısmi açık kenarlardan etkilenmektedir; taşıma ve kurulum esnasında ilave geçici çaprazlama gibi destekler gerektirir. Kısmi açık kenarlı modüller, mevcut binalara yeni banyo ve balkon eklemek amaciyla renovasyon ve mevcut binaya ilave yapılması durumunda kullanılabilir. Konstrüksiyon formu ilave dikmeler (Genellikle 70x70-100x100 SHS) hariç aynı kapalı modül gibidir. Açık kısa kenarlı modüllerin açık kenarları rijit çerçeveli yapılarak genellikle bu cephe çaprazlamalara gerek kalmadan tamamen cam cephe yapılabilir. Ayrıca yine rijit birleşimli olması nedeni ile bu cepheye balkon veya yürüme yolu eklenebilir. (Lawson, M., Ogden, R., Goodier, C., 2014; Detail 1974/2,s.216).

Tüm modül çeşitleri enine, boyuna ve karma doğrultularda büyütülerek farklı plan şemaları elde edilebilir. Az katlı yapılarda hem üstüste oturtularak yığma yapı sistem veya bir iskeletin içine yerleştirilerek taşıtılabildiği gibi çok katlı yapılarda ise taşıyıcı bir destek
Şekil: 18

Kapalı ve açık modüller enine veya boylamasina doğrultularda büyüyebilme esnekliğine sahiptir (Detail 1974/2,5.216)
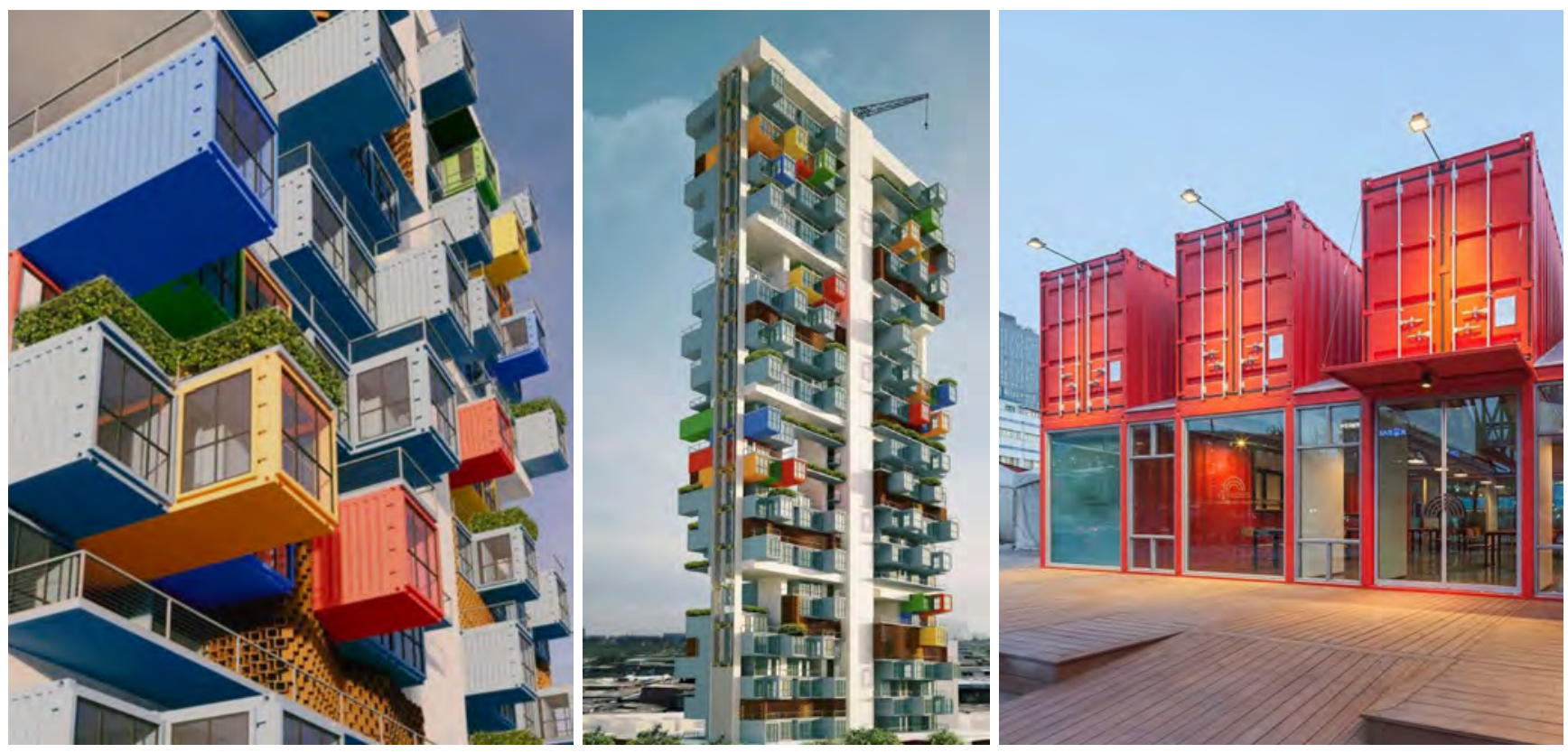
sistemine ihtiyaç vardır. Modüller iskelet sisteminin içine sürüldüğg̈nde her bir modül alttan, üstten veya yanlardan taşıyıcı sisteme taşıtılır. Modül ağırlığına bağlı olarak modüller taşıyıcıya asılarak da taşıtılabilir (Şekil 18; Resim 25, 26, 27).

\section{Nakliye ve Montaj}

Genellikle projenin etkin tamamlanma süresi modüler ünitelerin üretiminden ziyade asansör ve karmaşık donanımların siparişine göre belirlenmektedir. Hareket ettirilebilir donanımlar daha sonra taşınabilirken sabit donanımlar, fabrikada yerleştirilir. Modüler binaya ait bir inşaat programı, tamamen şantiye tekniklerinin kullanıldığı bina inşaatlarına kıyasla \%50 daha azdır. Şantiye içi inşaat süreleri, geleneksel inşaatlardaki 45 haftalık süreden prefabrike banyolara sahip hafif çelik yapılarda 33 haftaya ve tamamen modüler inşaatlarda ise 22 haftaya kadar indirilebilmektedir. (Lawson, M., Ogden, R., Goodier, C., 2014). Üretilecek olan ünitelerin boyutları, karayollarındaki kısıtlamalar ve trafik kanunları göz önüne alınarak belirlenmektedir. Taşıma esnasında sorunlarla karşılaşılmaması için modüllerin nakledileceği alana olan ulaşım yollarının bu doğrultuda incelenmesi gerekmektedir.

Nakliye için en uygun olan modüler üniteler, yükseklik olarak max. $2.3 \mathrm{~m}$ ve uzunluk olarak ise uluslararası nakliye koşullarına bağlı olarak (DIN 15190). max. 12.2 m olmalıdır. Modüler üniteler özellikle taşıma işlemi esnasında hava geçirmez nitelikte olmalıdır, çünkü rüzgar çarpması nedeniyle hasar oluşma riski söz konusudur. Bu nedenle üniteler genellikle inşaat süresince yerinde kalan ağır plastiklerle kaplanmaktadır. Büyük boyutlu modüllerin taşınması gerektiği durumlarda polis koruması eşliğinde "uzun ve geniş araç" nakliyelerine ihtiyaç duyulur. Bu tür nakliyelerin genellikle gündüz gerçekleştirilmesi mümkün olamayacağından zaman planlaması büyük ölçüde kısıtlanmaktadır.Modül kutular ya fabrikada ya da şantiyede istiflenip hazır bulundurulması maliyeti yükseltir. Modüllerin fabrikada bitirilir bitirilmez şantiye alanına gönderilmesi, burada da bekletilmeden yerine yerleştirilmesi gerekir. Modüler üniteleri şantiyedeki diğer işler nedeniyle oluşabilecek hasarlardan korumak amacıyla gerekli tedbirler alınmalıdır. Normal şartlarda kaldırma işlemi, ünitelerin tepesinden yapılır, ancak küçük ünitelerin ve bölmelerin de tabandan kaldırılması mümkündür(Lawson, M., Ogden, R., Goodier, C., 2014; Detail, 2008; Detail Dergisi, 2001)

\section{Değerlendirme}

Modüler kutu sistemler ile bina yapımı 1940'larda beton üretim teknolojileri ile denenmiş daha sonra sistemin ağırlığı nedeni ile uygulanması terk edilmişdir. Daha sonra hafif çelik sistemlerin ahşap iskelet sistemlerin yerine alternatif yapım yöntemi olarak geçmesi ile hızlı ve kaliteli bina üretimini destekleyecek yeni bir uygulama olarak tasarımcıların karşısına çıkmıştır. Özellikle tekrar eden hacimlerin olduğu binaların hızlı ve kaliteli üretilmesinde modül sistemlerin etkili olduğu görülmüştür. Az katlı yapılar kadar çok katlı yapılar içinde etkili bir yapım yöntemi olan modüler kutu sistemler ile binanın tamamı veya bir bölümü özellikle diğer yapım sistemleri ile inşa edilmiş çok katlı yapılarda servis şaftlarının modüler kutulardan yapıldığı çok sayıda uygulama mevcuttur.

Açık, yarı açık modül ünitelerinin yanyana gelmesi ise istenilen boyutlarda mekanlar elde edilebilir, bunun dışındaki boyutlarda ise geleneksel yapım sistemleri ile karma kullanılabilmesi de sistemin kendi içinde kapalı olmadığını göstermektedir. Yapılan çeşitli araştırmalar sadece iki modül kullanılarak çok sayıda konut plan alternatiflerinin üretilebilmesi tasarımcının özellikle belli fonksiyonlar içinde çok esnek tasarımlar yapabileceğini göstermektedir. Farklı boyutlarda modül kullanımı, modülleri birbiri üzerinde ileri geri kaydırmalar, birbiri üzerinde farklı doğrultulara yerleştirmeler, balkon ilaveleri vb ile tasarımlar zengileşmektedir. Bu sistemi sadece yeni bir tasarımında değil mevcut yapılara yapılacak eklemeler içinde verimli olduğu unutulmamalıdır. Nakliye koşullarına bağlı olarak genellikle dikdörtgen formlu üretilse de, daire, altıgen plan şemalı, kısa cephenin 
eğimli ve farklı geometrik formlarda üretildiği modüler kutularda mevcuttur. Bunlar açık ve yarı açık modüller olarak veya iki parçalı olarak yapılmaktadır.

Modüler kutu yapım sistemi binanın yapım süresinin kısaltılması, erken hizmete açılma, kalite, değiştirilebilirlik gibi çok sayıda avantajı ile tasarımcıların projeleri için alternatif yapım sistemlerinden bir olmuştur. Ayrıca, modüllerin sökülebilir ve yeni bir şantiyede orijinal formlarında yeniden kullanılabilir olmasıda sistemin yüksek seviyede sürdürülebilir olduğunu göstermektedir• 


\section{Kaynakça}

Altın M., (2013), Bir Sürdürülebilir Mimarlık Örneği: Otonom Binalar - Dymaxion Evi, Ege Mimarlık. Baldwin, J. (1996), Bucky Works: Buckminster Fuller's Ideas for Today, John Wiley \& Sons.

Bock, T., 2006-5, Lightweight Construction and Systems, Detail ; p.483-484,.

Burns, C., (2001), A Manufactured Housing Studio: Home On the Highway, Journal of Architectural Education no. 55 (1):51-57. Chia-Chang Hsu, Chih Ming Shis, (2006), A Typological Housing Design: The Case Study Of Quartier Fruges In Pessac By Le Corbusier, JAABE Vol.5,No:1.

Cook P., Chalk W., Crompton D., Greene D., Ron Herron, Mike Web,(1999), Archigram, Princeteon Architectural Press,

Davies, C., (2005), The Prefabricated Home, Reaktion Books, London.

Detail Dergisi, (1974), Volume:2

Detail Dergisi, (2001). Volume:4, pp.443-460

Emmit, S. ve Gorse, C., (2010), Barry's Advanced Construction of Buildings, 2nd edition.

Eren, Ö., (2014), Hafif Çelik Yapı Tasarım Konstrüksiyon Uygulama, Arı Sanat Yayınları, İstanbul.

Erturan, B. ve Eren, Ö., (2012), Modüler Yapım Tekniği ile Bina Etkinliğini ve Verimliliğini Geliştirme Yaklaşımının Değerlendirilmesi, NWSA-Engineering Sciences, New World Sciences Academy vol:7, Number:4, 1 A0334.

Eşsiz, Ö., Koman, İ., (Mart 2007), Modüler Hücre sistemlerle Güncel Uygulamalar, Yapı Dergisi.

G. Herbert, (1978), Pioneers of Prefabrication: The British Contribution in the Nineteenth Centurty, Johns Hopkins University Press.

G. Staib, A. Dorrhofer, M. Rosenthal, (2008), Components and Systems: Modular Construction, Design, Structure, New Technologies, Edition Detail, Birkhauser

Kronenburg, R., (1995), Houses in Motion, Academy Editions, London.

Lawson, M., Ogden, R., Goodier, C., (2014), Design in Modular Construction, CRC Press, London.

M. Schoenborn, J., (2012), A Case Study Approach to Identifying the Constraints and Barriers to Design Innovation for Modular Construction, Master of Science

Shih, (2002), Le Corbusier - The Legend In $20^{\text {th }}$ Century Architecture, Taipei, Ecus Publishing Company.

Smith,R.,(2010), Prefab Architecture, A Guide to Modular Design and Construction, John Wiley \& Sons, Canada.

Sunay Ç., (2017), Astronotlar Üşür mü?. Türkiye İşBankası Yayınları

Weller, K., (1989), Industrielles Bauen 2. Industrielle Fertigung und Anwendung von Montagebauweisen aus Stahlbeton, Stahl, Holz und Entwicklung zum umweltbewussten Bauen. Stuttgart / Berlin / Cologne / Mainz

Zainal Abidin, A.R.B.,(2007). Simulatıon Of Industrıalısed Building System Formatıon For Housing Constructıon, Master Thesis. Malasia: Universiti Teknologi Malasia Faculty of Civil Engineering.

URL-1: Improving Construction Efficiency \& Productivity with Modular Construction, Modular Building Institute, Charlottesville, https://www.modular.org/.../Whitepaper_Improving ConstructionEfficiency. Pdf, (erişism Aralık 2018).

URL-2: Kaynak: pinterest,(erişim 2018)

URL-3: solsken.com, (erişim 17 Kasım 2018)

URL-4: web: apps.acsa-arch.org/resources/.../streamfile.aspx?path...98...pdf, (erişim temmuz 2018)

URL-5: O’Day, K., (2009), Tropical or Colonial?: A Reception History of Jean Prouve's Prefabricated Houses for Africa, Louisiana State University, web.mit.edu/yourhouse/. (erişim Temmuz 2018)

URL-6. Anon, (2009), Utah Trucking Guide. Motor Carrier Division, Utah Department of Transportation, Edition. http:// utahmc.com/trucking_guide (erişim Ağustos 2018)

URL-7: Tomas U., Ganiron Jr, Almar M.,(2014), Prefabricated Technology in a Modular House, International Journal of Advanced Science and Technology Vol.73, http://dx.doi.org/10.14257/ijast.2014.73.04 (erişim Ağustos 2018)

URL-8.web.mit.edu/yourhouse/yourHOUSE\%20brochure.pdf', (erişim 1 Aralık 2018)

URL-9: muza-chan.net, (erişim Ağustos 2018)

URL-10: https://www.designingbuildings.co.uk/wiki/Habitat_67や(erişim Ağustos 2018)

URL 11:https://www.theguardian.com/.../habitat-67-montreal-expo-moshe-safdie- history-cities-50-buildings-day-35|(erişim Ağustos 2018)

URL-12. montreall.com (erişim Ağustos 2018)

URL-13: Arkitektuel.com (erişim Ağustos 2018)

URL-14: architecturalvisits.com (erişim Ağustos 2018)

URL-15:divisare.com (erişim Ağustos 2018)

URL-16:https://www.designboom.com/architecture/idin-architects-lima-duva-resort- koh-samed-thailand-09-18-2015//(erişim Aralık 2018)

URL-17: Detail, 2008 (erişim Mayıs 2018)

URL-18: http:utzero.utk.edu/docs/SustainablePrefab/CaseStudies_CarwrightPickardArchitects_Murray Grove Apartments. pdfł(erişim Mayıs 2018)

URL-19: http://utzero.utk.edu/docs/SustainablePrefab/CaseStudies_DollmannPartner_OfficeBlock. pdf, (erişim Ağustos 2018)

URL-20: Baldwin, J. (2012), Dymaxion House. Buckminster Fuller Institute: http://www.bfi.org/about-bucky/buckys-bigideas/dymaxion-world/dymaxion-house (erişim Haziran 2018)

URL-21: https://www.turkiyegazetesi.com.tr/dunya/4002.aspx,Türkiye Gazetesi 09.01.2012, Çinliler 360 saatte 30 katll otel yaptı (erişim Ekim 2018)

URL-22: v3.arkitera.com

URL-23: pinterest.com 